\title{
Forest Structure and Composition under Contrasting Precipitation Regimes in the High Mountains, Western Nepal
}

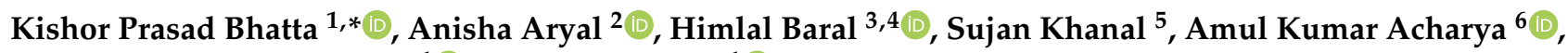 \\ Chanthavone Phomphakdy ${ }^{1}(\mathbb{B})$ and Rinzin Dorji ${ }^{1}$ (D)
}

1 Faculty of Forest Science and Forest Ecology, Georg-August-Universität, 37077 Goettingen, Germany; yoctvppd@hotmail.com (C.P.); rinzin.dorji@stud.uni-goettingen.de (R.D.)

2 Faculty of Environmental Sciences, Technische Universität Dresden, 01737 Dresden, Germany; anisaaryal22@gmail.com

3 Center for International Forestry Research (CIFOR), Jalan CIFOR, Situ Gede, Bogor 16115, Indonesia; H.Baral@cgiar.org

4 School of Ecosystem and Forest Sciences, University of Melbourne, Parkville, VIC 3010, Australia

5 Federation of Community Forestry Users, Nepal (FECOFUN), Duwakot 44800, Nepal; info.sujankhanal@gmail.com

6 Forest Research and Training Centre, Babar Mahal, Kathmandu 44600, Nepal; acharya.amulkumar@gmail.com

* Correspondence: k.bhatta@stud.uni-goettingen.de

Citation: Bhatta, K.P.; Aryal, A.; Baral, H.; Khanal, S.; Acharya, A.K.; Phomphakdy, C.; Dorji, R. Forest Structure and Composition under Contrasting Precipitation Regimes in the High Mountains, Western Nepal. Sustainability 2021, 13, 7510. https:/ / doi.org/10.3390/su13137510

Academic Editor: Petros Ganatsas

Received: 2 June 2021

Accepted: 29 June 2021

Published: 5 July 2021

Publisher's Note: MDPI stays neutral with regard to jurisdictional claims in published maps and institutional affiliations.

Copyright: (c) 2021 by the authors. Licensee MDPI, Basel, Switzerland. This article is an open access article distributed under the terms and conditions of the Creative Commons Attribution (CC BY) license (https:/ / creativecommons.org/licenses/by/ $4.0 /)$.

\begin{abstract}
The high mountains stretch over 20.4\% of Nepal's land surface with diverse climatic conditions and associated vegetation types. An understanding of tree species and forest structural pattern variations across different climatic regions is crucial for mountain ecology. This study strived to carry out a comparative evaluation of species diversity, main stand variables, and canopy cover of forests with contrasting precipitation conditions in the Annapurna range. Firstly, climate data provided by CHELSA version 1.2, were used to identify distinct precipitation regimes. Lamjung and Mustang were selected as two contrasting precipitation regions, and have average annual precipitation of $2965 \mathrm{~mm}$ and $723 \mathrm{~mm}$, respectively. Stratified random sampling was used to study 16 plots, each measuring $500 \mathrm{~m}^{2}$ and near the tree line at an elevation range of 3000 to $4000 \mathrm{~m}$ across different precipitation conditions. In total, 870 trees were identified and measured. Five hemispherical photos using a fisheye lens were taken in each plot for recording and analyzing canopy cover. Margalef's index was used to measure species richness, while two diversity indices: the Shannon-Wiener Index and Simpson Index were used for species diversity. Dominant tree species in both study regions were identified through the Important Value Index (IVI). The Wilcoxon ranksum test was employed to determine the differences in forest structure and composition variables between the two precipitation regimes. In total, 13 species were recorded with broadleaved species predominating in the high precipitation region and coniferous species in the low precipitation region. Higher species richness and species diversity were recorded in the low precipitation region, whereas the main stand variables: basal area and stem density were found to be higher in the high precipitation region. Overall, an inverse J-shaped diameter distribution was found in both precipitation regions signifying uneven-aged forest. A higher proportion of leaning and buttressed trees were recorded in the high precipitation region. However, similar forest canopy cover conditions $(>90 \%)$ were observed in both study regions. The findings of this research provide a comprehensive narrative of tree species and forest structure across distinct precipitation regimes, which can be crucial to administrators and local people for the sustainable management of resources in this complex region.
\end{abstract}

Keywords: precipitation; diversity; mountain; Annapurna

\section{Introduction}

Forest structure, composition, and diversity patterns are crucial ecological features that correlate significantly with prevailing environmental and anthropogenic components [1-3]. 
Stand structure and species composition are essential for forest biodiversity, and an understanding of these is the basis of sustainable forest management [4]. Forest structure and composition also have a vital role in the global carbon budget as they act as huge C-pools [5]. Tropical forests are hotspots of biodiversity, and their geographical variation depends on their evolutionary history and climatic conditions [6,7]. Comparisons in tropical forests have illustrated that mountain forests are usually shorter and less diverse than forests in the lowlands $[8,9]$. In addition to altitudinal gradient, regional climate plays a major role in influencing forest structure. It is usually inferred that forests in higher precipitation and temperature regions have taller trees and more biomass [10,11]. Furthermore, precipitation has been demonstrated to have a positive effect on tree diameter and the basal area of forests $[12,13]$. The shaping and configuration of forests are thus largely affected by changes in climate variables [14]. Over the past decades, upward shifts in tree species and tree lines have been documented owing to rises in temperature $[6,15]$.

The relationship between species diversity and climatic effects has been analyzed in recent studies [16,17]. Field et al. [16] developed a model that describes the relationship between climate and plant richness, while Francis and Currie [17] developed a model for angiosperms. Higher species richness has been recorded with increasing temperatures up to a certain point, where richness diminishes due to water deficiency [16,18]. While Goldie et al. [19] found that in arid regions, water availability plays an important role in the evolutionary processes of woody plants and these processes are diminished by persistent drought, around $63 \%$ of global variability in angiosperm richness and $68 \%$ in woody plant family richness, explained by precipitation $[16,17,20]$. Similarly, a positive relationship was established between species richness and precipitation up to $4000 \mathrm{~m}$ in a neotropical region [21]. However, the relationship between species richness and temperature is found to be negative under limited water availability [18].

Due to the complex and diverse topographies and rain-shadow effects of high mountains, the Himalayan region of Nepal is characterized by significant local variations in climate [22]. The orographic effect of the Himalayan range plays an important role in determining the distribution of precipitation in this area. At a large scale, precipitation has been vital for determining species richness [23], composition [24], and distribution [25-28]. Vegetation monitoring allows in-depth analyses of components like moisture and temperature, and delivers knowledge on subtle monsoon variations for the Himalayas [29]. Likewise, species-environmental interactions can be applied as indicators of environmental conditions, and the diversity and forest patterns can be used to explain ecological phytogeography [12,30]. The fragile ecology of Himalayan forests is well-known [31]. However, fundamental knowledge of the structure and composition of Himalayan forests is limited in many regions [32]. Moreover, an understanding of how forest structure and diversity vary between different precipitation regimes is still lacking [33-36].

The high mountain region of Nepal has the highest forest proportion with forests covering $37.81 \%$ of the total land area [37]. Moreover, this region has been characterized by strong contrasts in precipitation regimes and forests, which are influenced by the effects of climate and land-use change. A better understanding of environmental factors influencing the distribution, abundance, and co-existence of tree species is crucial in forest ecology. Therefore, in this study, we examined the species diversity, species distribution, and stand structure of forests in contrasting precipitation regimes of the high mountain. The study aims to provide a better understanding of phytogeography in this complex region. This study may provide better insights on composition and structure in the mountain forests and would be highly applicable to several mountainous countries for the sustainable management of forest resources. The main objective of our study is to assess the forest structure and composition of high mountain forests in two contrasting precipitation conditions. To achieve the main objective of this study, we strived to address two main questions: (1) Are there any variations on forest composition and structure across contrasting precipitation conditions? (2) If so, how do the forest composition and structure vary with contrasting precipitation conditions? 


\section{Materials and Methods}

\subsection{Study Area}

The high mountains area stretches from longitudes of $80^{\circ} 30^{\prime} 4^{\prime \prime}$ to $88^{\circ} 07^{\prime} 04^{\prime \prime} \mathrm{E}$ and latitudes of $26^{\circ} 59^{\prime} 15^{\prime \prime}$ to $30^{\circ} 06^{\prime} 47^{\prime \prime} \mathrm{N}$, covering approximately $20.4 \%$ of the total land area of Nepal [37]. This study was carried out in the Annapurna Mountain range of Nepal. The Annapurna range or Annapurna massif (Figure 1) lies in the north-central part of Nepal and covers several peaks, including Annapurna $(8091 \mathrm{~m})$, the tenth highest mountain in the world [38]. The range covers five districts of Nepal, namely: Kaski, Lamjung, Manang, Mustang and Myagdi. It covers a total area of around $11,930 \mathrm{~km}^{2}$ with $36 \%$ forest cover (see Appendix A) [39].

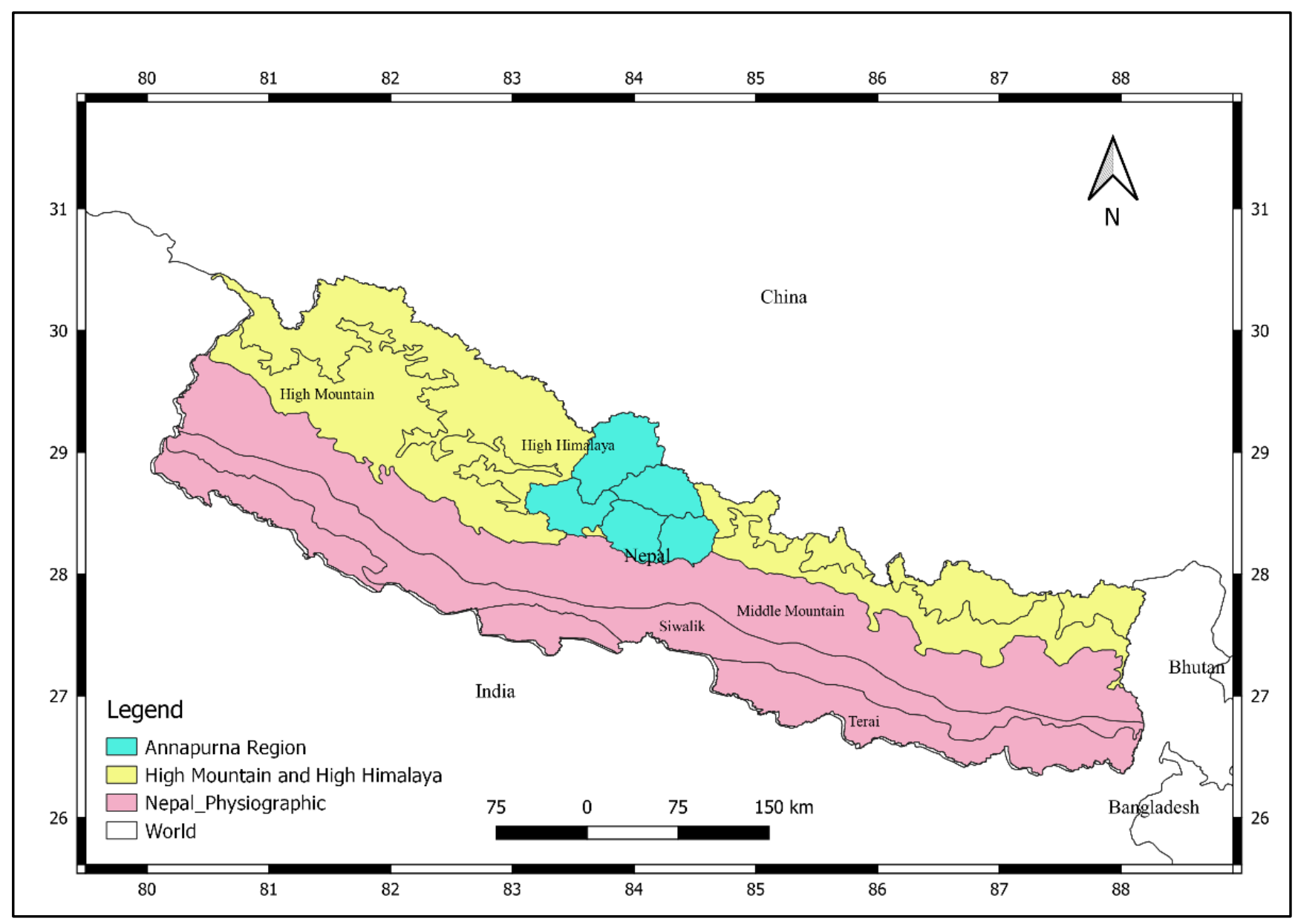

Figure 1. Physiographic zones of Nepal and the Annapurna region.

The region is bounded by the Marshyangdi valley in the east, the Kali Gandaki river in the west, the dry alpine desert of Mustang in the north, and the valleys and foothills of Pokhara in the south [40]. The presence of the Annapurna massif has created strong variations in climate across the region. Spanning $120 \mathrm{~km}$ with altitudes of below $1000 \mathrm{~m}$ up to $8000 \mathrm{~m}$, it has two distinct climatic regions [40]. The southern belt of this range - the Pokhara region - receives the highest precipitation, while the northern belt- the trans-Himalayan region-receives the lowest precipitation in Nepal [41]. Nepal's largest conservation area, the Annapurna Conservation Area (ACA), covers most of this range and is situated between $83^{\circ} 34^{\prime}$ to $84^{\circ} 25^{\prime} \mathrm{E}$ and $28^{\circ} 15^{\prime}$ to $28^{\circ} 50^{\prime} \mathrm{N}$, covering an area of $7629 \mathrm{~km}^{2}$. ACA is rich in biodiversity, harbors 29 ecosystem types [42,43] and has a wide range of habitats, from Shorea robusta to perennial snow forests, harboring 22 different forest types. Schimwa wallichi, Castanopsis indica, Alnus nepalensis, Pinus wallichiana and Betula utilis are the region's major tree species [44]. The primary type of disturbances in this region are 
grazing, timber cutting, firewood collection, leaflitter collection and collection of other non-timber forest products [40].

As this study strives to compare forest composition and structure between two different climatic conditions, intensive study sites were selected by analyzing precipitation conditions over the ACA region using the CHELSA (Climatologies at high resolution for the Earth's land surface areas) version 1.2 global climate dataset [45] (http: / / chelsa-climate.org/, (accessed on 21 September 2020)). The dataset provides monthly and annual precipitation and temperature patterns for the period from 1979 to 2013. Other climate analysis studies in Nepal, e.g., [41,46-49] were also used as references for study area selection. Two intensive study sites (Table 1, Figure 2) were selected for the contrasting precipitation regimes, caused by the strong orographic effects of Annapurna massif. Bhujung, Lamjung lies on the windward side, while Kobang, Mustang is on the leeward side of the Annapurna range. Climatic conditions in the intensive study sites are presented in Section 2.2.

Table 1. Descriptions of intensive study sites in the Annapurna range differentiated by contrasting precipitation regimes.

\begin{tabular}{ccc}
\hline Precipitation Regime & Study Site & Location \\
\hline High/Humid & Bhujung, Lamjung (here after “Lamjung”) & $28^{\circ} 22^{\prime} 47^{\prime \prime} \mathrm{N}, 84^{\circ} 15^{\prime} 27^{\prime \prime} \mathrm{E}$ \\
Low/Dry & Kobang, Mustang (here after “Mustang") & $28^{\circ} 40^{\prime} 29^{\prime \prime} \mathrm{N}, 83^{\circ} 35^{\prime} 04^{\prime \prime} \mathrm{E}$ \\
\hline
\end{tabular}

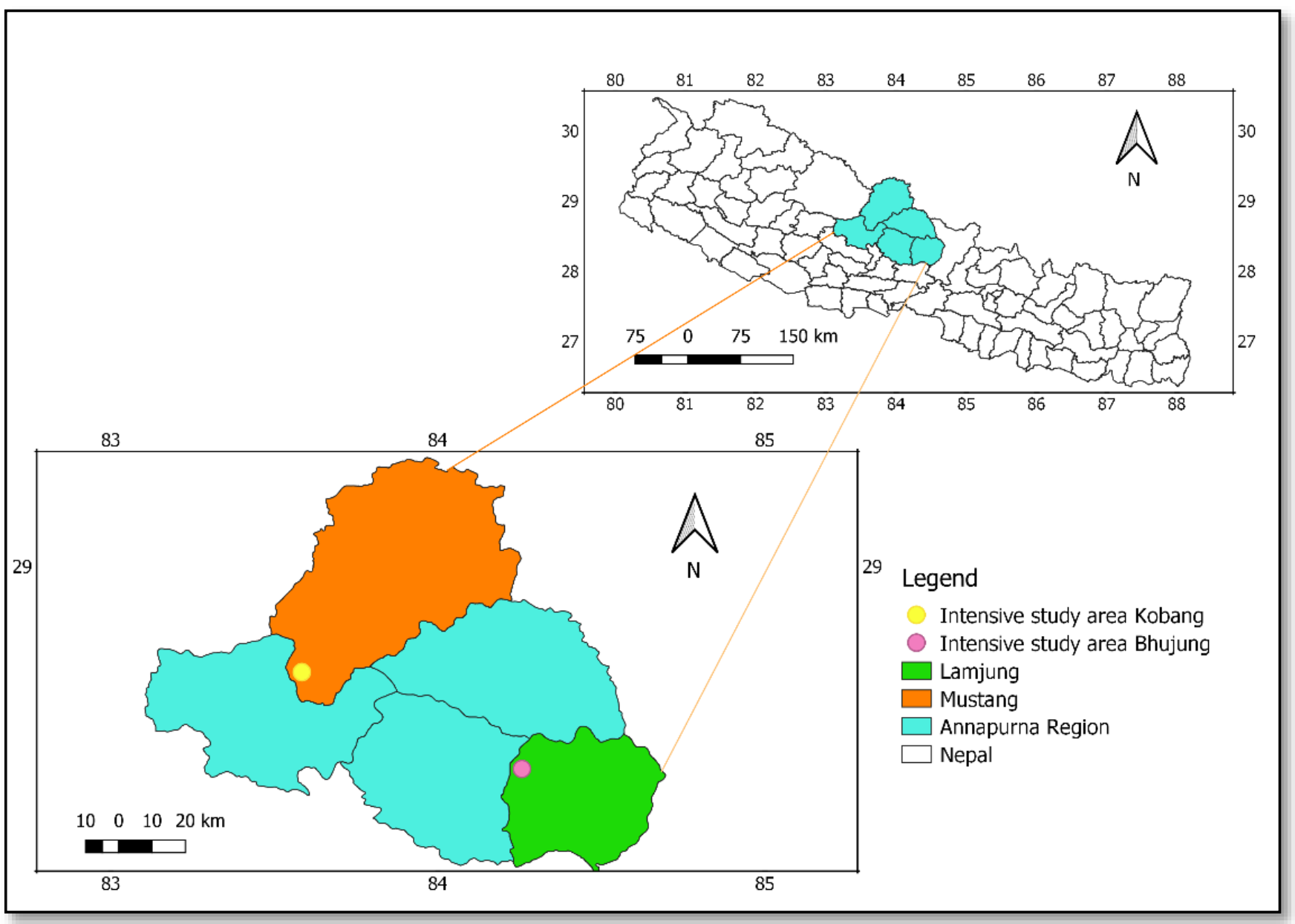

Figure 2. Map showing the intensive study sites: Lamjung and Mustang. 


\subsection{Climatic Conditions in the Intensive Study Sites}

Average annual precipitation in the high precipitation region (Lamjung) is $2965 \mathrm{~mm}$, as depicted through the climate diagram [50] (Figure 3a). The average temperature in Lamjung is $3.9^{\circ} \mathrm{C}$, with a maximum average temperature of $14.3^{\circ} \mathrm{C}$ in July and a minimum of $-12.3^{\circ} \mathrm{C}$ in January. The region receives higher precipitation from June to September, with an average of more than $500 \mathrm{~mm}$.

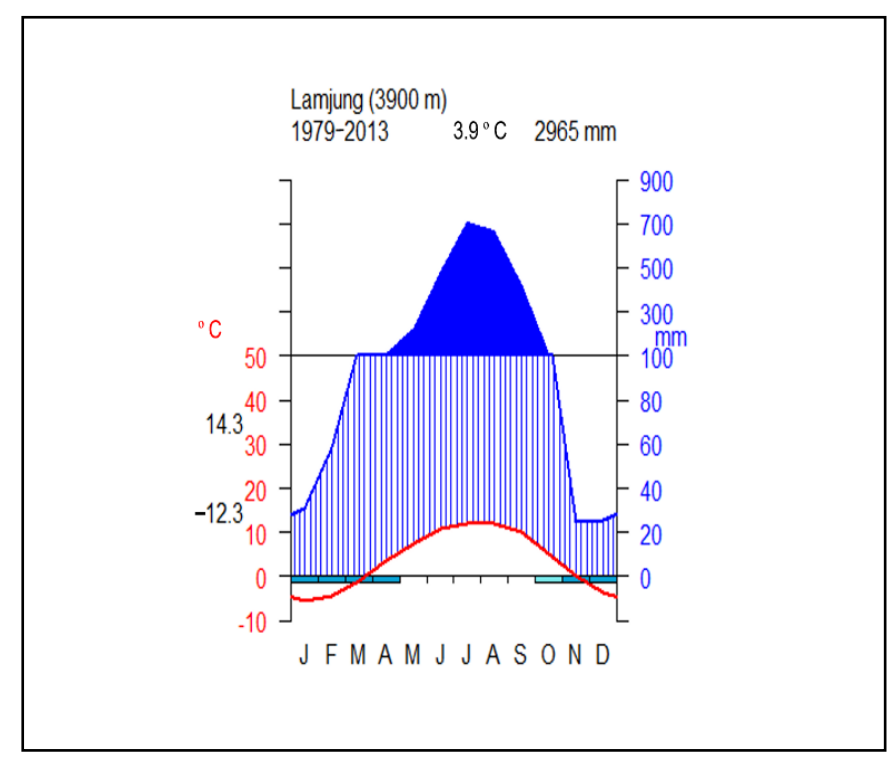

(a)

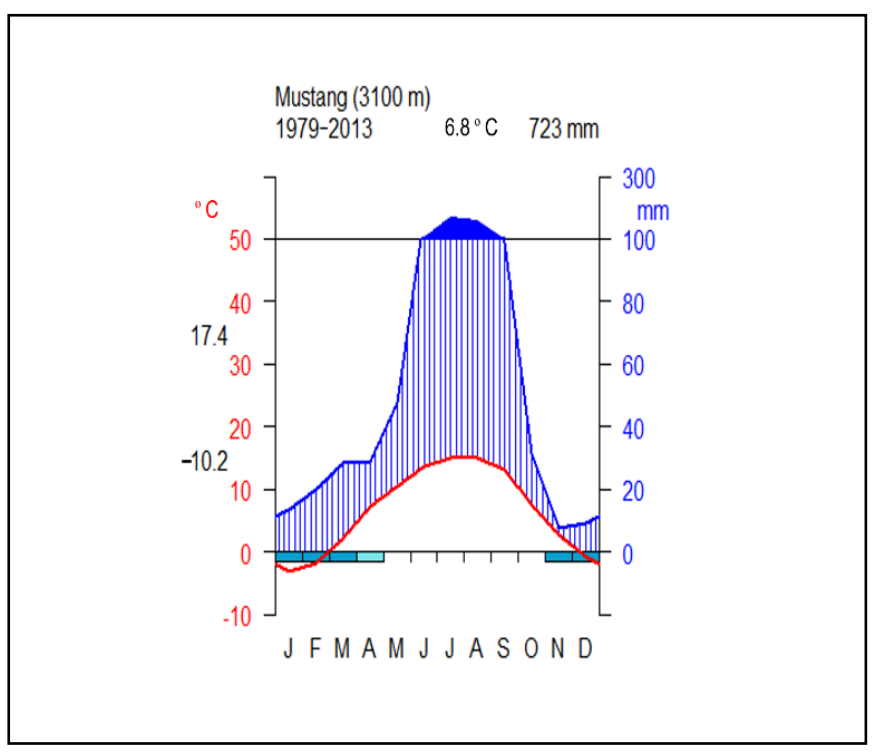

(b)

Figure 3. Climate diagrams based on CHELSA data (1979-2013) for both study sites prepared using the Climatol package [51] in R-studio [52]. (a) Climate diagram for Lamjung where the light blue box for October signifies probable frost condition while definite frost conditions for six months from November to April are represented by dark blue boxes (b) Climate diagram for Mustang where the definite frost conditions for five months from November to March are indicated by the dark blue boxes while likely frost conditions in April is indicated by the light blue box. Letters in the x-axis of both (a) and (b) denote months.

The climate diagram for the low precipitation region (Mustang) (Figure 3b) shows average annual precipitation of around $723 \mathrm{~mm}$ and an average temperature of $6.8^{\circ} \mathrm{C}$. In Mustang, the maximum average temperature is $17.4^{\circ} \mathrm{C}$ in July with a minimum of $-10.2^{\circ} \mathrm{C}$ in January. The four months from June to September receive the highest precipitation with averages above $100 \mathrm{~mm}$.

Seasonal analyses of precipitation for both study sites were carried out based on the four seasons prevalent in Nepal: pre-monsoon (March-May), monsoon (June-September), post-monsoon (October-December) and winter (January-February) [48]. In both study sites, around $75 \%$ of precipitation occurred during the monsoon season (June-September) (see Table 2). Winter precipitation contributes more to total annual rainfall in the drier Mustang region. The greatest variation in precipitation for both study sites was in the post-monsoon season (coefficient of variation-CV: 74.1\% for Lamjung, and 69.29\% for Mustang).

Table 2. Average seasonal and annual precipitation and CV based on CHELSA data (1979-2013). Values in brackets are $\mathrm{CV}$ percentages.

\begin{tabular}{cccccc}
\hline Study Site & $\begin{array}{c}\text { Winter } \\
\text { (January-February) } \\
(\mathbf{m m})\end{array}$ & $\begin{array}{c}\text { Pre-Monsoon } \\
\text { (March-May) } \\
(\mathbf{m m})\end{array}$ & $\begin{array}{c}\text { Monsoon } \\
\text { (June-September) } \\
(\mathbf{m m})\end{array}$ & $\begin{array}{c}\text { Post-Monsoon } \\
\text { (October-December) } \\
(\mathbf{m m})\end{array}$ & $\begin{array}{c}\text { Annual } \\
(\mathbf{m m})\end{array}$ \\
\hline \multirow{2}{*}{ Lamjung } & 89.41 & 441.37 & 2273.94 & 160.74 & 2965.40 \\
& $(64.80)$ & $(33.30)$ & $(15.10)$ & $(74.19)$ & $(13.00)$ \\
Mustang & 32.25 & 105.08 & 535.82 & 48.54 & $(1423.00$ \\
& $(58.10)$ & $(31.49)$ & $(14.67)$ & $(69.29)$ & $(12.00)$ \\
\hline
\end{tabular}




\subsection{Geology and Soil in the Intensive Study Area}

Our study sites: Lamjung and Mustang lie in two upper most tectonic plates namely Greater Himalayan Sequence (GHS) and Tethyan Himalayan Sequence (THS) respectively [53]. The underlying rocks in both study sites are mainly Gneisses, migmatite and some parts with limestone, shales, and sandstone in northern Mustang [54,55]. The soil sample (0-15 cm deep) from the center of each plot was collected to determine the physical and chemical properties. Both study sites were characterized by acidic soil conditions and high level of soil nutrients, whereas medium range of soil organic matter (Table 3). The method used to test the soil properties and the ranking chart used by the Soil Management Directorate Nepal [56] is presented in Appendix B.

Table 3. Physical and chemical properties of soil for both study sites.

\begin{tabular}{|c|c|c|c|c|c|c|}
\hline \multirow[b]{2}{*}{ Study Site } & \multirow[b]{2}{*}{ Soil Texture } & \multirow[b]{2}{*}{ Average Soil pH } & \multirow[b]{2}{*}{$\begin{array}{c}\text { Average Soil } \\
\text { Organic Matter (\%) }\end{array}$} & \multicolumn{3}{|c|}{ Soil Nutrients * } \\
\hline & & & & $\begin{array}{c}\text { Average } \\
\text { N (\%) }\end{array}$ & $\begin{array}{c}\text { Average } \mathrm{P}_{2} \mathrm{O}_{5} \\
\left(\mathrm{Kg} \mathrm{ha}^{-1}\right)\end{array}$ & $\begin{array}{c}\text { Average } \mathrm{K}_{2} \mathrm{O} \\
\left(\mathrm{Kg} \mathrm{ha}^{-1}\right)\end{array}$ \\
\hline Lamjung & Loam & 4.75 & 4.70 & 0.23 & 159.73 & 561.00 \\
\hline Mustang & Loam & 6.20 & 5.15 & 0.26 & 154.43 & 561.30 \\
\hline
\end{tabular}

* Soil Nutrients: N- Nitrogen, $\mathrm{P}_{2} \mathrm{O}_{5}$ - Phosphorus pentoxide, $\mathrm{K}_{2} \mathrm{O}$ - Potassium oxide

\subsection{Data Collection}

Forest inventories for 16 plots ( 8 plots at each study site) were employed to acquire information on forest composition and structure and assess them under different climatic conditions. Systematic random sampling was employed for this study. The first plot was established randomly and remaining plots in a tentative straight line in the same direction with $100 \mathrm{~m}$ distances between plots. Rectangular sampling plots, each with an area of $500 \mathrm{~m}^{2}(25 \mathrm{~m} \times 20 \mathrm{~m})$ were established at each study site based on Nepal's National Inventory Guideline [57]. Slope correction was carried out for plots on slopes with gradients of $>10 \%$, as slope correction is mainly applied for slopes exceeding $10 \%$ [58]. Slope angle was measured using a clinometer. The true horizontal distance was calculated using the formula:

$$
\mathrm{L}=\mathrm{Ls} \times \cos \mathrm{S}
$$

where ' $\mathrm{L}$ ' is the true horizontal distance, ' $\mathrm{Ls}^{\prime}$ is the measured distance along the slope, and ' $\mathrm{S}$ ' is the slope in degrees.

The area was then calculated using the true horizontal distance, and adjustments to plot area were made during analysis. Sampling plots were established near the tree line to determine tree line species in the Annapurna range. Total enumeration was done during forest inventory as most trees in higher elevations were dwarf trees. The brief research design framework is illustrated in Figure 4. In Lamjung, the sample plots lay at elevations of 3700 to $4000 \mathrm{~m}$ in southern aspect with average steepness of $38^{\circ}$ while in Mustang they were at 3000 to $3100 \mathrm{~m}$ in northern aspect with average steepness of $42^{\circ}$ near the tree line. Tree lines in the Annapurna region lie between 3600 and $3700 \mathrm{~m}$ on southern slopes, while tree line elevation increases considerably, entering high mountain massifs, i.e., 4000 to $4100 \mathrm{~m}[59,60]$. With an increment in distance from Annapurna, the timberline elevation decreases again [60]. In the southwestern part of Mustang, tree lines dominated by Abies spectabilis and Pinus wallichiana can be found at elevations from 2900 to $3500 \mathrm{~m}$ [61].

All trees (stems) inside the research plots were measured other than seedlings. In total, 870 trees were measured in the two study sites: 549 in Lamjung and 321 in Mustang. Species name, DBH (diameter at breast height) and total height were recorded for each tree. Diameter tape was used for DBH measurement and a Suunto height meter for height measurement with measurement accuracy of $0.1 \mathrm{~cm}$ and $0.1 \mathrm{~m}$, respectively. To analyze mountain forest canopy cover, hemispherical photographs were taken of each plot. In total, 80 hemispherical photographs (five for each plot) were recorded. In each plot, one photograph was taken at the center of the plot, and the remaining four were 
taken $5 \mathrm{~m}$ inside each border, at a $5 \mathrm{~m}$ distance from plot corners (Figure 5). A DSLR (Digital Single Lens Reflex) camera (Nikon, Model-D5300) and fisheye lens (Sigma Circular

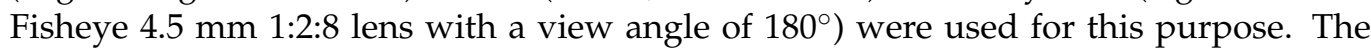
hemispherical photographs were taken according to the Beckschäfer method [62] at a height of $1.5 \mathrm{~m}$ during windless weather and standard overcast condition [63]. In addition, to assess the variability of mountain forest leaf sizes in two distinct precipitation conditions, 50 leaves/leaflets were collected for each species (a total of 650 leaves/leaflets) maintaining a representation of all three layers of crown: lower, middle, and top. For coniferous species, the size of a single needle was measured, considering the leaflet. The areas of around 576 leaves/leaflets were measured: 400 in Mustang and 176 in Lamjung. The remaining samples were deemed unacceptable due to shape distortion. The Leaf Byte app [64] iOS (iPhone Operating System) version was used for measuring leaf area.

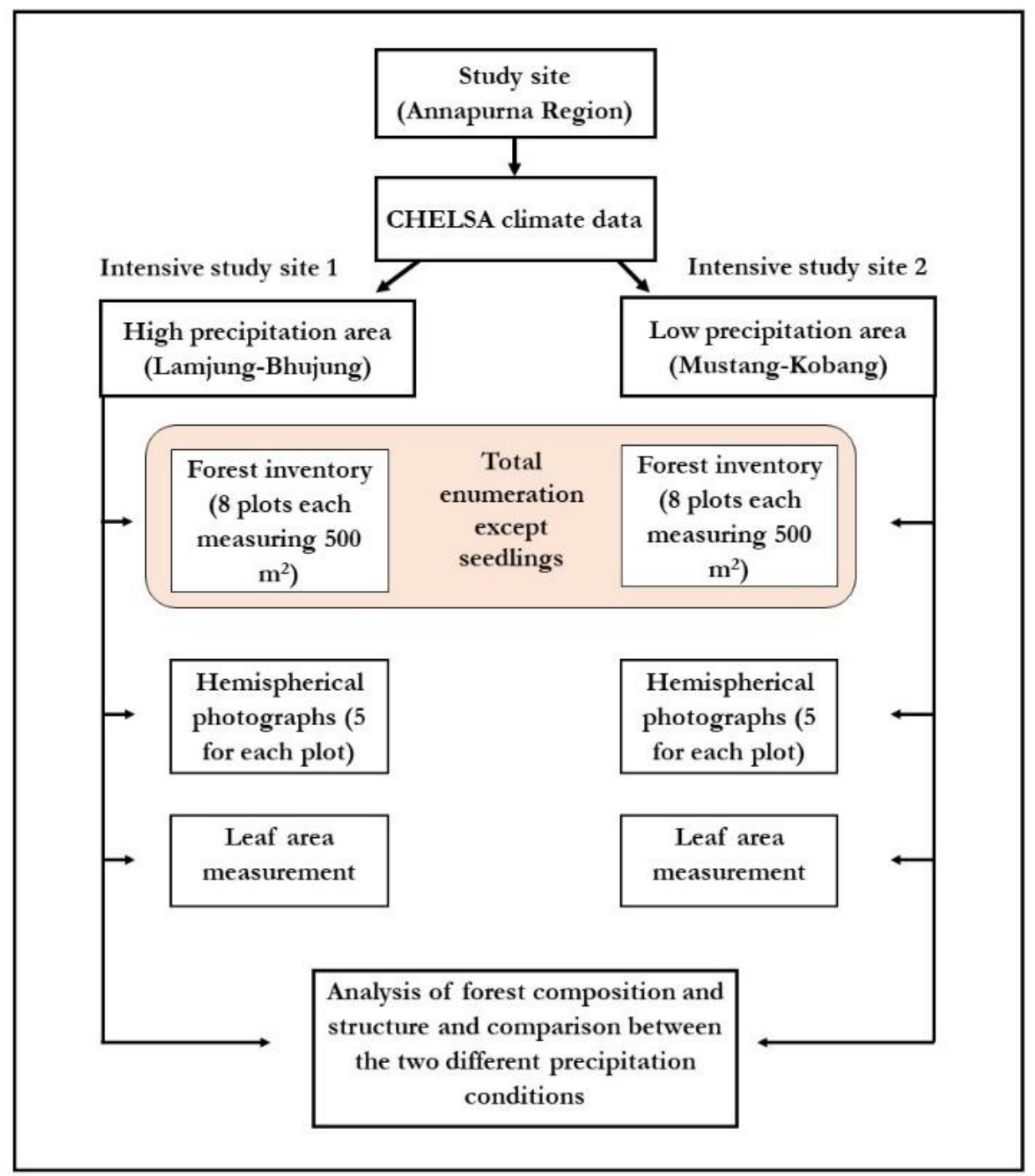

Figure 4. Research design. 


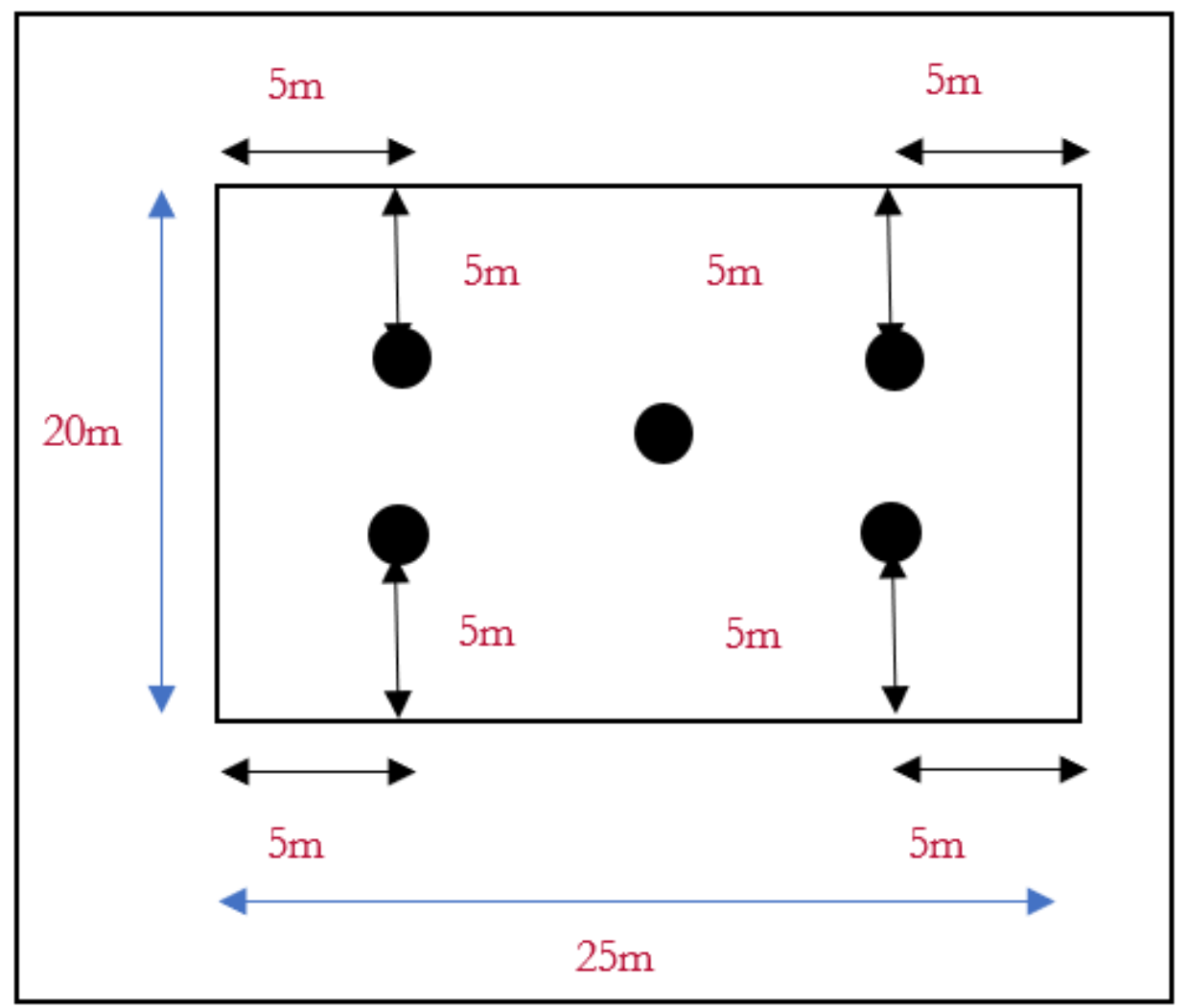

Figure 5. Research design for capturing hemispherical photographs in each study plot.

\subsection{Data Analysis}

Firstly, a list of tree species recorded in both study sites was developed. The ShapiroWilk test [65] was used to assess the normality assumption which showed the collected field data were not normally distributed. General stand variables, such as basal area $\left(\mathrm{m}^{2} \mathrm{ha}^{-1}\right)$, quadratic mean diameter $(\mathrm{cm})$, stem density (stems ha $\left.{ }^{-1}\right)$, mean canopy height $(\mathrm{m})$, volume $\left(\mathrm{m}^{3} \mathrm{ha}^{-1}\right)$ were calculated using descriptive statistics. Species diversity, species richness [66], and species evenness [67] were generated using the vegan [68] package in R-studio [52]. Species diversity was measured using two indices: the Shannon-Wiener Index [69] and Simpson's Index [70]. Additionally, a boxplot in R-studio [52] was used to visualize diversity indices, species richness, and species evenness. A tree diameter distribution graph was prepared using the inventory data for both study sites, which were crucial for describing forest structures and functions [71]. In simple terms, the histograms of frequencies of individual stems per hectare divided into diameter classes determined the tree distribution patterns in stands [72]. The R-studio [52], tidyverse [73] and ggplot2 [74] packages were used to visualize diameter frequency distribution. Important Value Index (IVI) was calculated for each species in both study sites to get an overview of important (dominant) species. The IVI was calculated by quantifying three components of each species: relative density, relative dominance, and relative frequency.

$$
\text { IVI = relative density }+ \text { relative dominance }+ \text { relative frequency }
$$

where: density $=$ number of individuals per ha, dominance $=$ basal area per ha, and frequency $=$ occurrence of certain species in respective sample plots:

Similarly:

relative density $=\frac{\text { Number of individuals of the species }}{\text { total number of individuals of all species }} \times 100 \%$

relative dominance $=\frac{\text { Total basal area of the species }}{\text { Total basal area of all species }} \times 100 \%$

relative frequency $=\frac{\text { percent of sample plots occupied by the species }}{\text { percent of the occurence of all species }} \times 100 \%$ 
Each of these values is expressed as a percentage ranging from $0 \%$ to $100 \%$. The IVI is the sum of these three components and can range from 0 to 300 (Adapted from [75]). The hemispherical photos were analyzed in ImageJ [76] using the Beckschäfer method [77]. At first, the hemispherical photos were converted to binary pictures and the pixel values of gap fraction and canopy cover were recorded. The pixel values of the canopy divided by the total pixel value provided the percentage of canopy cover. The Wilcoxon rank-sum test, also called the Mann-Whitney U test [78], was used for the statistical analysis in this study. In R-studio [52], the wilcox.test was used to examine the statistical significance of differences observed in inventory analysis findings between the study sites.

\section{Results}

\subsection{Forest Composition}

\subsubsection{Species Recorded and Their Main Features}

In total, 13 species were recorded near the tree lines during the field studies (Table 4). In Lamjung, five species: Betula utilis, Juniperus indica, Rhododendron campanulatum, Salix nepalensis and Sorbus microphylla were recorded, while in Mustang eight species: Abies spectabilis, Acer campbellii, Cotoneaster microphyllus, Elaeagnus parviflora, Ilex dipyrena, Pinus wallichiana, Rhododendron arboreum, and Taxus wallichiana were recorded.

Table 4. Species recorded in both study sites along with elevations and main features.

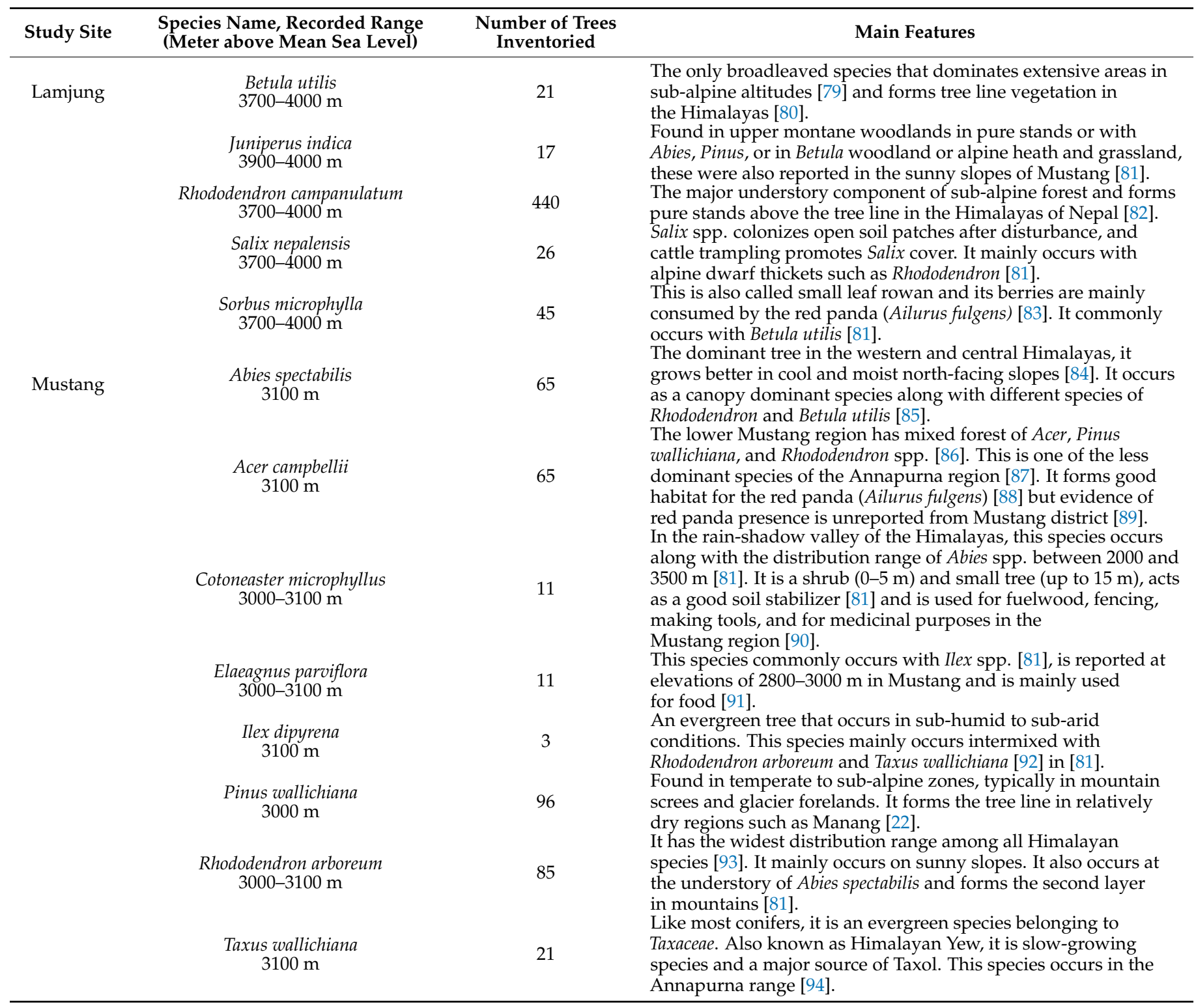




\subsubsection{Species Evenness, Richness, and Diversity}

Before assessing the species diversity indices of our study sites, species evenness and richness were analyzed (Figure 6a). Mustang had higher species evenness $(0.76 \pm 0.03)$ and species richness $(0.84 \pm 0.06)$ than Lamjung (evenness- $0.47 \pm 0.03$ and richness$0.48 \pm 0.02$ ). Similarly, statistically significant differences were observed between the two study sites in terms of species evenness ( $W=7, p$-value: 0.006$)$ and species richness ( $W=9$, $p$-value: 0.014). The higher Shannon index and Simpson index values for forests in Mustang indicate higher species diversity in comparison to Lamjung. A significant difference was observed between the two study sites for species diversity based on the two diversity indices ( $\mathrm{W}=8, p$-value: 0.01$)$. Shannon index values varied from $0.53 \pm 0.01$ to $1.01 \pm 0.03$ between Lamjung and Mustang. Similarly, the Simpson index value was $0.28 \pm 0.01$ for Lamjung and $0.55 \pm 0.06$ for Mustang (Figure 6b).

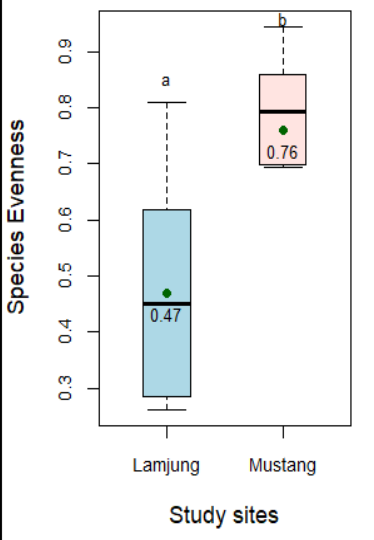

(a)

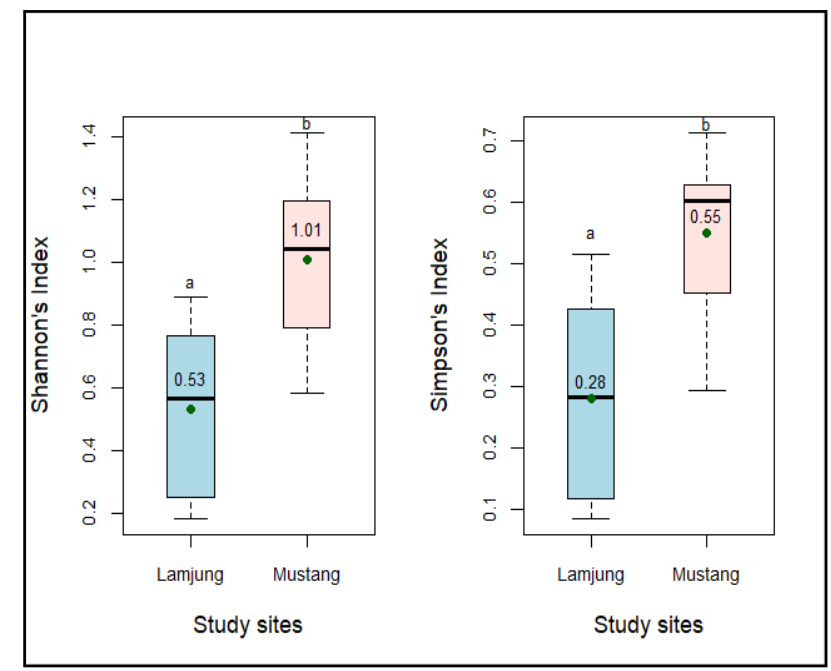

(b)

Figure 6. (a) Comparison of species evenness and species richness; (b) Comparison of species diversity, between the study sites. The different letters $(\mathbf{a}, \mathbf{b})$ denote significant differences between mean values.

\subsubsection{Species Distribution}

In Lamjung, Rhododendron campanulatum was found to be the dominant species (Table 5). It had an abundance of 1100 stems ha ${ }^{-1}$, a basal area of $16.4 \mathrm{~m}^{2} \mathrm{ha}^{-1}$, and a frequency of $100 \%$. The least dominant tree species was Juniperus indica with an abundance of 43 stems ha ${ }^{-1}$, and a frequency of only $13 \%$ in the study site. This study site was dominated by broadleaved species with few undergrowth of coniferous species. In Mustang, Abies spectabilis was the most dominant species (Table 6). It had an abundance of 163 stems ha ${ }^{-1}$, a basal area of $13.4 \mathrm{~m}^{2} \mathrm{ha}^{-1}$, and a frequency of $50 \%$. Ilex dipyrena was the least dominant species in Mustang with a stem density of 8 stems ha $^{-1}$ and a frequency of only $13 \%$. The study site in Mustang was found to be dominated by two coniferous species: Abies and Pinus in addition to the broadleaved species Rhododoendron arboreum, which had a frequency of $100 \%$, signifying its presence in all research plots.

\subsection{Forest Structure}

\subsubsection{Diameter Frequency Distribution}

The diameter frequency distributions of all species in the total study area and in the precipitation, conditions differentiated study sites signifies the presence of natural forest in the region (Figure 7). Except for trees below $10 \mathrm{~cm}$ diameter, both study sites showed an inverse J-shaped curve, indicating that numbers of trees decrease as diameters increase. The highest proportion of trees belonged to the $10-20 \mathrm{~cm}$ diameter class (around $51 \%$ in Lamjung and $37 \%$ in Mustang). The $>80 \mathrm{~cm}$ diameter class accounted for only $0.18 \%$ of 
trees in Lamjung and $0.37 \%$ in Mustang. The inverse J-shaped curve was more pronounced for Lamjung. Diameters of measured trees varied from 3.9 to $96 \mathrm{~cm}$ in Lamjung, and 2.1 to $84 \mathrm{~cm}$ in Mustang.

Table 5. IVI analysis of tree species for the study site in Lamjung.

\begin{tabular}{|c|c|c|c|c|}
\hline Species Name & Abundance [n ha $\left.{ }^{-1}\right]$ & Basal Area $\left[\mathrm{m}^{2} \mathrm{ha}^{-1}\right]$ & Frequency [\%] & IVI \\
\hline Rhododendron campanulatum & 1100 & 16.4 & 100 & 171.9 \\
\hline Sorbus microphylla & 112 & 5.3 & 88 & 56.1 \\
\hline Betula utilis & 53 & 5.6 & 63 & 44.5 \\
\hline Salix nepalensis & 65 & 0.6 & 38 & 19.5 \\
\hline Juniperus indica & 43 & 0.2 & 13 & 8.0 \\
\hline Total & 1373 & 28.0 & & 300 \\
\hline
\end{tabular}

Table 6. IVI analysis of tree species for the study site in Mustang.

\begin{tabular}{|c|c|c|c|c|}
\hline Species Name & Abundance [n ha $\left.{ }^{-1}\right]$ & Basal Area $\left[\mathrm{m}^{2} \mathrm{ha}^{-1}\right]$ & Frequency [\%] & IVI \\
\hline Abies spectabilis & 163 & 13.4 & 50 & 85.9 \\
\hline Pinus wallichiana & 240 & 7.7 & 63 & 76.0 \\
\hline Rhododendron arboreum & 213 & 2.3 & 100 & 60.7 \\
\hline Acer campbellii & 73 & 0.6 & 38 & 20.6 \\
\hline Cotoneaster microphyllus & 28 & 0.2 & 63 & 19.7 \\
\hline Taxus wallichiana & 53 & 0.9 & 25 & 16.5 \\
\hline Elaeagnus parviflora & 28 & 0.1 & 50 & 16.4 \\
\hline Ilex dipyrena & 8 & 0.1 & 13 & 4.2 \\
\hline Total & 806 & 25.2 & & 300 \\
\hline
\end{tabular}

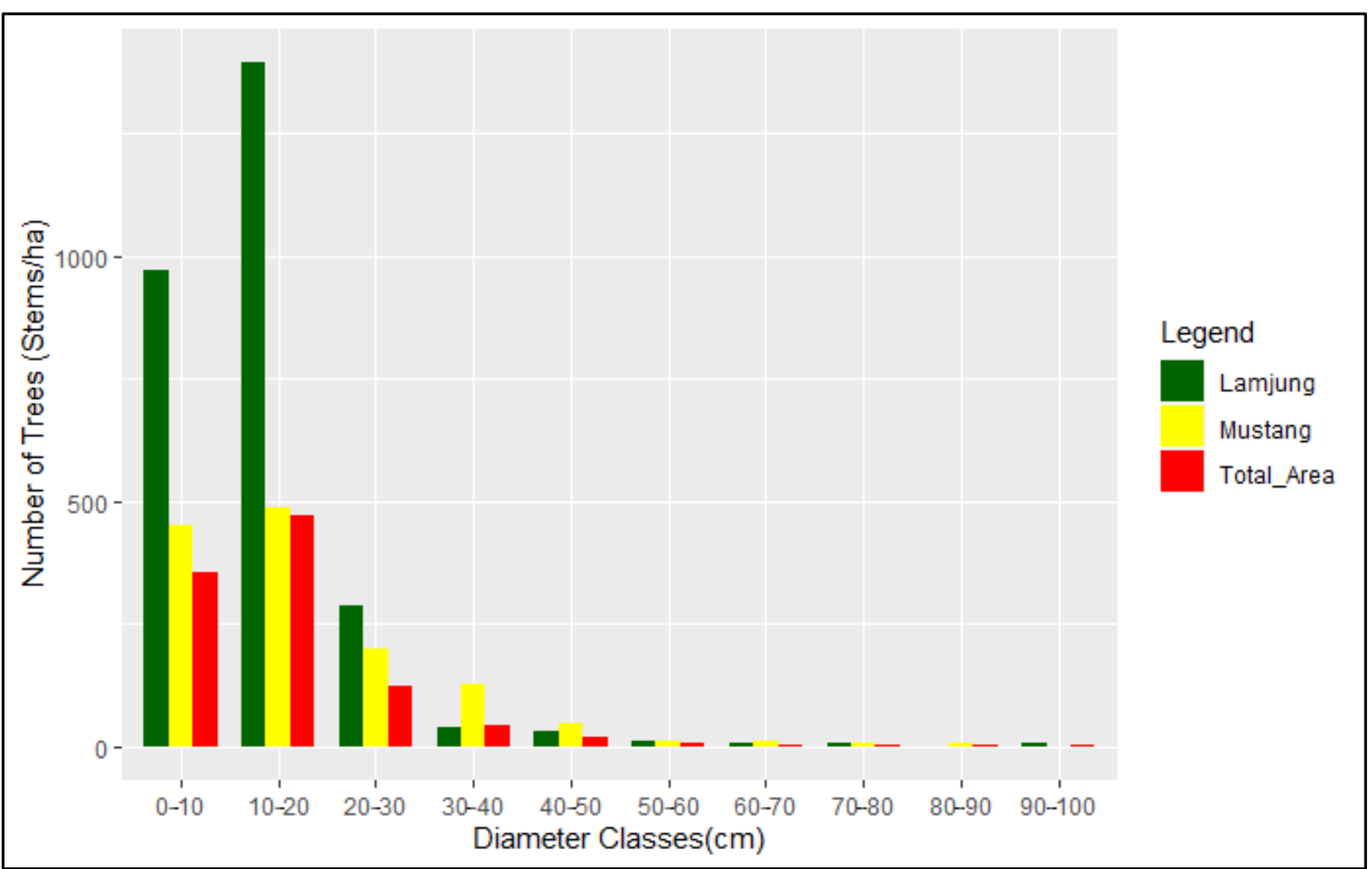

Figure 7. Diameter frequency distribution for both study sites. 


\subsubsection{Main Stand Variables and Health Attributes of Trees}

Both horizontal and vertical stand variables were derived in this study. The main stand variables, such as basal area, quadratic mean diameter (QMD), stem density, mean tree height, and tree volume were generated for both study sites (Table 7). The forest in Lamjung had a higher basal area and stem density than forest in Mustang. Average basal area was approximately $28 \mathrm{~m}^{2} \mathrm{ha}^{-1}$ for forest in Lamjung, and $25 \mathrm{~m}^{2} \mathrm{ha}^{-1}$ for Mustang with no significant difference between mean values. There was significant difference in stem density between the two study sites, where Lamjung and Mustang had stem densities of 1373 stems ha $^{-1}$ and 806 stems ha $^{-1}$, respectively. QMD values were $16.12 \mathrm{~cm}$ for the forest in Lamjung, and $21.53 \mathrm{~cm}$ for Mustang, with no statistically significant difference between the two study sites. Average tree height was roughly double in Mustang (10.2 m) compared to Lamjung $(5.2 \mathrm{~m})$, with a statistically significant difference. Stem volume ranged from $102.68 \mathrm{~m}^{3} \mathrm{ha}^{-1}$ in Lamjung to $282.47 \mathrm{~m}^{3} \mathrm{ha}^{-1}$ in Mustang. The higher volume in Mustang might be due to the higher QMD and mean tree height values in the area, though no statistically significant difference was observed in mean values for volumes between the study sites. Moreover, analyzing the hemispherical photographs (Figure 8a,b) of both study sites showed similar canopy cover, i.e., $>90 \%$ (Figure 8c) with no statistically significant difference $(\mathrm{W}=24, p$-value: 0.43$)$.

Table 7. Main stand variables for both study sites generated from forest inventory data.

\begin{tabular}{ccccc}
\hline Stand Variable & Lamjung & Mustang & Wilcoxon Test Statistics $(\mathbf{W})$ & $\boldsymbol{p}$-Value \\
\hline Basal Area $\left(\mathrm{m}^{2} \mathrm{ha}^{-1}\right)$ & 28.03 & 25.19 & 40 & 0.44 \\
Stem density $\left(\mathrm{stems} \mathrm{ha}^{-1}\right)$ & 1373 & 806 & 52 & 0.037 \\
Quadratic mean diameter $(\mathrm{cm})$ & 16.12 & 21.53 & 20 & 0.23 \\
Mean tree height $(\mathrm{m})$ & 5.2 & 10.2 & 1 & 0.0003 \\
Volume $\left(\mathrm{m}^{3} \mathrm{ha}^{-1}\right)$ & 102.68 & 282.47 & 17 & 0.13 \\
\hline
\end{tabular}

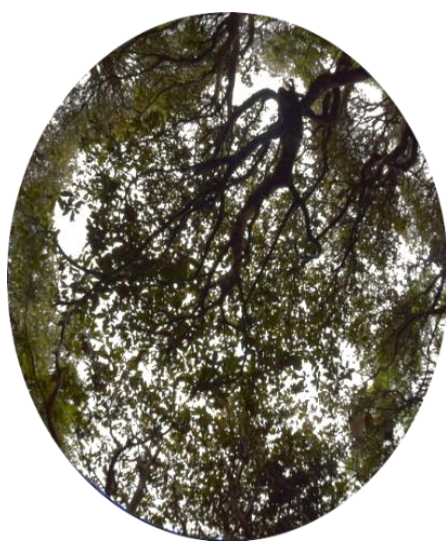

(a)

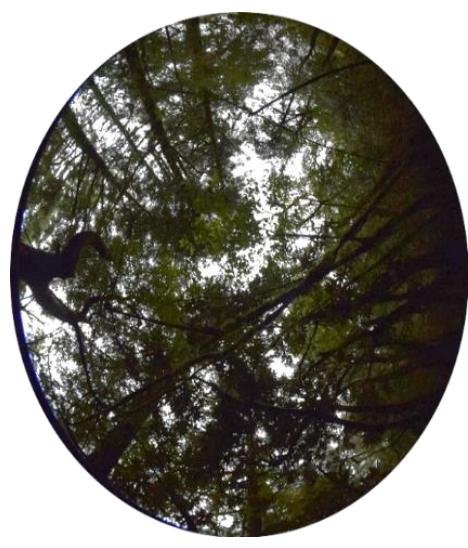

(b)

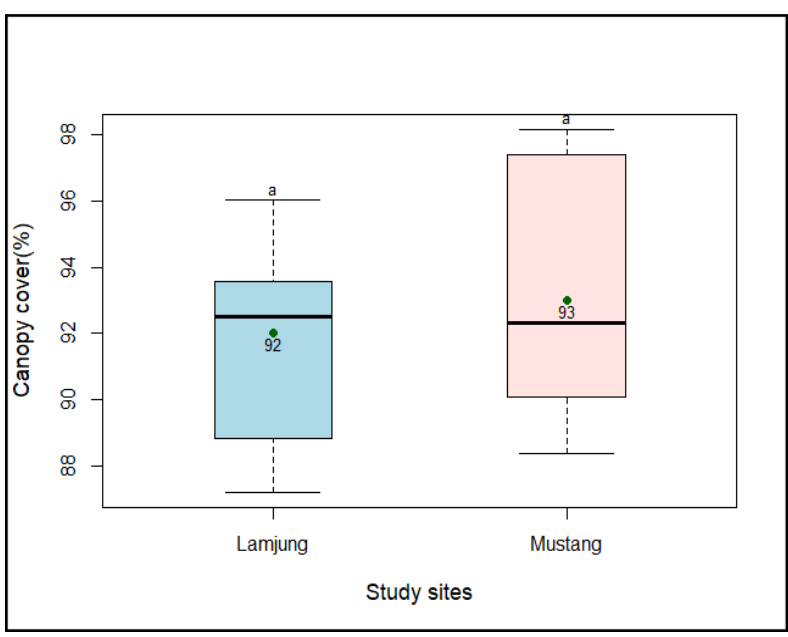

(c)

Figure 8. Sample hemispherical photographs captured in Lamjung (a) and Mustang (b), and canopy cover of forests in Lamjung and Mustang (c) where a denotes non-significant difference between the mean values.

Comparisons of five health and morphological attributes, namely: dead/dying trees, the presence of buttresses, leaning trees, crooked trees, and trees with broken crowns, were made between the two study sites (Figure 9). Lamjung had higher proportions of leaning $(>60 \%)$ and buttressed trees (39\%) in comparison to Mustang. The forest in Lamjung had the highest values for all attributes except for broken crowns, while crooked trees were absent from the forest in Mustang. 


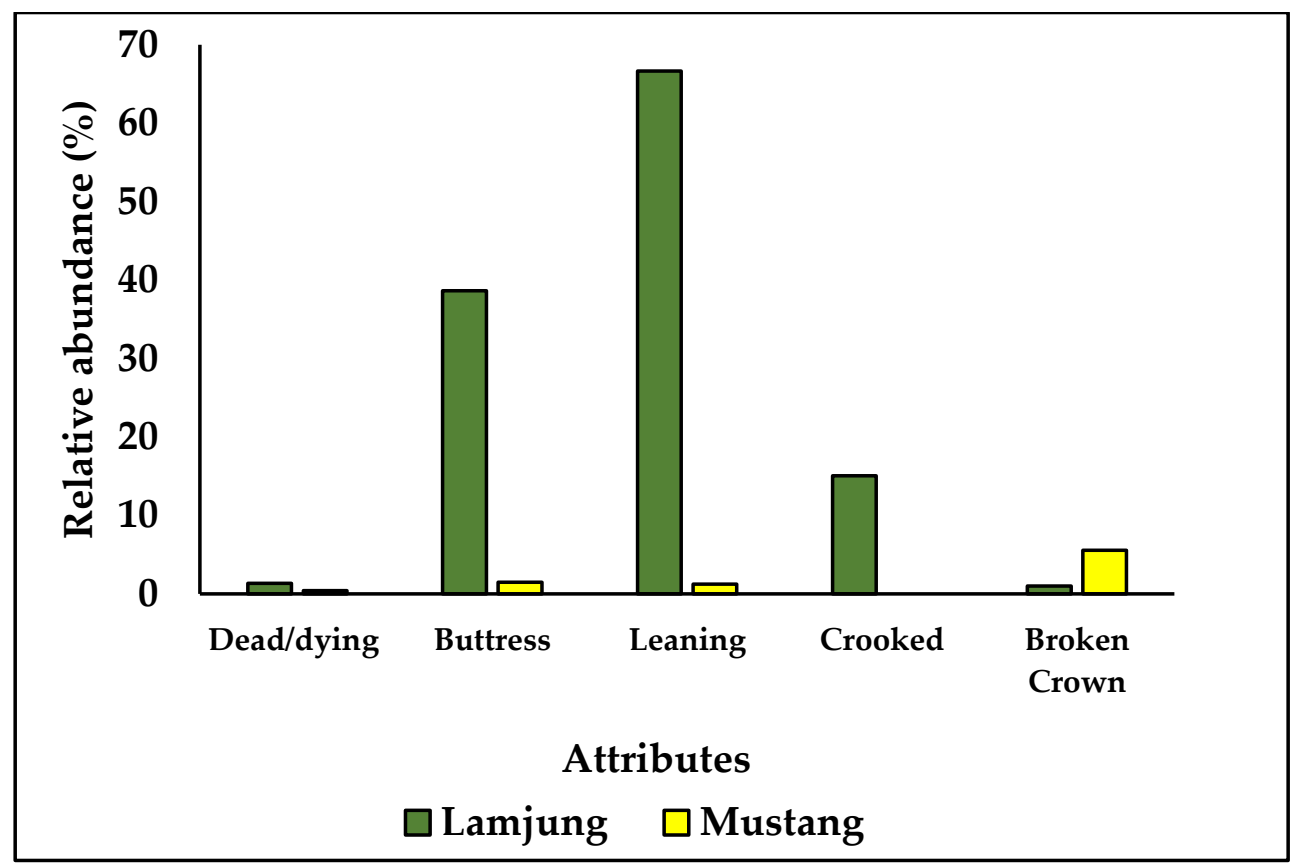

Figure 9. Relative abundance of tree health and morphological attributes in both study sites.

\subsubsection{Leaf Sizes of Mountainous Tree Species}

Leaf sizes of the species recorded during the study differed significantly between the forests with different precipitation conditions (Table 8). In the high precipitation region, the dominant species, Rhododendron campanulatum, had the biggest leaf size at $40.94 \pm 2.30 \mathrm{~cm}^{2}$, while Sorbus microphylla had the smallest leaf size at $2.48 \pm 0.15 \mathrm{~cm}^{2}$. The only recorded coniferous species: Juniperus indica in Lamjung had the needle/leaflet size at $0.44 \pm 0.03 \mathrm{~cm}^{2}$. The sparsely recorded broadleaved species in Mustang i.e., Rhododendron arboreum, was found to have the largest leaf size at $31.29 \pm 1.80 \mathrm{~cm}^{2}$. Among the coniferous species recorded in Mustang, Pinus wallichiana had the largest needle/leaflet size at $0.65 \pm 0.02 \mathrm{~cm}^{2}$.

Table 8. Average leaf areas of species recorded in the study sites.

\begin{tabular}{cccc}
\hline Study Site & Species Name & Average Leaf Area $\left.\pm \mathbf{~ s e} \mathbf{( c m}^{\mathbf{2}}\right)$ & Species Type \\
\hline Lamjung & Betula utilis & $31.70 \pm 2.95$ & Broadleaved \\
& Juniperus indica & $0.44 \pm 0.03$ & Coniferous \\
& Rhododendron campanulatum & $40.94 \pm 2.30$ & Broadleaved \\
& Salix nepalensis & $11.00 \pm 0.70$ & Broadleaved \\
& Sorbus microphylla & $2.48 \pm 0.15$ & Broadleaved \\
Mustang & Abies spectabilis & $0.47 \pm 0.12$ & Coniferous \\
& Acer cambellii & $21.11 \pm 2.40$ & Broadleaved \\
& Cotoneaster microphyllus & $8.90 \pm 0.76$ & Broadleaved \\
& Elaeagnus parviflora & $26.42 \pm 2.99$ & Broadleaved \\
& Pinus wallichiana & $0.65 \pm 0.02$ & Coniferous \\
& Ilex dipyrena & $25.27 \pm 2.40$ & Broadleaved \\
& Rhododendron arboreum & $31.29 \pm 1.80$ & Broadleaved \\
& Taxus wallichiana & $0.53 \pm 0.03$ & Coniferous \\
\hline
\end{tabular}

\section{Discussion}

Climate variables, especially precipitation, strongly influence vegetation distribution and composition through impacts on water availability and local weather conditions [95,96]. The spatiotemporal patterns of vegetation at upper tree lines in mountains are largely determined by soil moisture $[97,98]$ and patterns differ between slopes due to differences 
in the presence of permafrost $[99,100]$. The two study sites varied only in terms of slope direction and precipitation while all other factors slope inclination, type of soil were almost similar. The most common species recorded near the tree line in Nepal are Abies spectabilis, Rhododendron campanulatum, Pinus wallichiana [84], Betula utilis [101], Sorbus microphylla, Salix spp. and Juniperus spp. [102], which supports our findings on the species encountered during this study. Dense Rhododendron campanulatum forest in the Lamjung site has also been documented in the Annapurna range by Schickhoff's study [59] on the timberline of the Hindu-Kush Himalayas. In this study, broadleaf forest with Rhododendron campanulatum and Betula utilis was found in the higher precipitation zone, whereas needleleaved forest with Abies spectabilis and Pinus wallichiana was found in the lower precipitation zone. The predominance of Rhododendron campanulatum, Sorbus spp. in mesic sites has been documented by Singh and Singh [103]. The evergreen species and large shrubs of Rhododendron spp. in areas dominated by monsoon precipitation have also been reported by Schickhoff [59]. The dominance of Pinus wallichiana in south-facing dry slopes, and Abies spectabilis and Rhododendron campanulatum in mesic slopes in the Himalayas of Nepal have been reported by many studies [22,59,104,105]. However, the presence of Abies spectabilis in a dry area like Mustang contradicts many studies $[61,81]$. The area near Kobang (Lete region) is estimated to receive more precipitation and therefore has a wider distribution of this species [106].

Many studies, e.g., [107-109] have mentioned climate variables, mainly precipitation and temperature, and their interactions as the main factors for variation in species richness. Species richness and species diversity were higher in Mustang than in Lamjung, which depicts the negative correlation between precipitation and diversity. The higher species richness and diversity in Mustang than Lamjung could be due to the differences in study plot aspects. The higher diversity recorded on the north-facing slopes of Mustang than the south-facing forest of Lamjung in this study concurs with other findings in Nepal $[110,111]$ and other parts of the globe [112,113]. In the northern hemisphere, south-facing slopes are usually warmer due to their higher levels of irradiance, which support drought-resistant vegetation and restrict tree growth, while north-facing slopes are cold and humid with higher soil moisture, which support a larger number of species [111]. Another reason for the higher number of species recorded in Mustang might be due to the higher precipitation in our study area (Kobang/Lete region) at $723 \mathrm{~mm}$ compared to the average of $200 \mathrm{~mm}$ for the Mustang region [48]. Increases in precipitation have been found to enhance species richness and plant diversity markedly by promoting soil moisture variability, especially in semi-arid and arid regions [114-116]. The difference in species richness and diversity between Mustang and Lamjung could be also due to the different elevations of the study sites, as species richness is believed to decrease with increases in elevation $[117,118]$. Though this is open to debate with other studies showing a hump-shaped relationship in the Himalayas [104,119].

The vague relationship between species richness and precipitation has been determined by different studies. A study in Eastern Himalaya in Bhutan showed the nil effect of precipitation on species richness. However, in different moisture regimes, temperature had a significant effect on species richness [120]. The non-significant effect of precipitation on species diversity is also reported by Stan and Sanchez-Azofeifa [121]. In contrast, the study by Kushwaha and Nandy [122] recorded lower species richness in dry forest than moist forests, stating that moisture availability affects the regeneration of tree species. In lower-elevation tropical forests, higher species diversity and richness were recorded in high precipitation regions than dry regions in Myanmar by Khaine et al. [123], and in mangrove forest [124] and sub-Saharan Africa [125] as well. Regarding forest structure, most studies $[1,32,126-128]$ have focused on Himalayan vegetation patterns along altitudinal gradients, though few have mentioned the importance of climate variables in predicting forest stand structure $[21,129,130]$. Considering forest structure varies with water availability [131], and environmental and biological factors control forest structure at higher elevations $[132,133]$, this study tried to assess differences in forest structure along a 
precipitation gradient in the Annapurna range. The higher stem density and basal area in Lamjung than Mustang signified a positive relationship between precipitation and forest structure. Similar to our findings, Khaine et al. [123] reported the strong influence of precipitation on forest structure in Myanmar. They found increases in basal area and stem density with precipitation increasing from 843 to 2035 mm. Muñoz Mazón et al. [131] also found an increase in basal area with increasing precipitation and decreasing temperature along the Atlantic slope of Talamanca Mountain. Higher basal area and stem density were observed in humid versus dry areas of forest in Brazil, and were attributed to precipitation seasonality [134]. Moreover, a strong relationship between climate variables and forest structure was observed in the Eastern Himalayan of India [135]. Restricted tree growth due to low water availability during long dry seasons is documented by Hiltner et al. [136]. Structural changes owing to changes in precipitation were also forecast by Hiltner et al. [136]. Similarly, Kushwaha and Nandy [122] discovered a strong relationship between precipitation and forest structure in West Bengal, India. The influence of annual precipitation on forest structure in tropical regions has also been documented by Beard [137]. A study by Duchesne and Ouimet [138] mentions the significant effects of precipitation on the structural development of forests over time. Basal area and density increased from younger to medium age stands, then decreased in older stands in sites with higher precipitation, whereas basal area showed a linear relationship with stand age in sites with lower precipitation [138]. According to Hiltner et al. [136], precipitation affects forest structure through its impact on moisture availability and therefore drought-tolerant species would show no significant change.

Furthermore, the inverse J-shaped pattern documented for overall size class distribution in this study is similar to the findings of Bhutia et al. [32] who found the highest number of individuals in the smallest DBH class of 3 to $13 \mathrm{~cm}$ and least in the highest class in Eastern Himalayan, India. This pattern is further supported by the findings of Shrestha et al. [139], Dar et al. [140], Pandey et al. [127], and Schwab [141]. More than 90\% of trees were found in lower diameter classes in the Himalayan forest of India [140]. Pandey et al. [127] recorded maximum percentages of trees in the DBH range of 10 to $29.9 \mathrm{~cm}$ in the transHimalayan region of Nepal. Most tree species in the Krummholz tree line of Rolwaling Himal, Nepal in the lower DBH range i.e., $0-14 \mathrm{~cm}$ were Abies spectabilis, Betula utilis, Sorbus microphylla and Rhododendron campanulatum [141]. This type of diameter distribution suggests an uneven-aged forest with enough young recruitment to replenish mature forest stands [142]. Although canopy cover analysis of mountain forests using fisheye lenses are rarely documented, the percentage of canopy cover recorded by this study is higher than observations made by Uniyal et al. [143] in the Garhwal Himalayan forest in India, and by Måren and Sharma [144] in the Langtang area of Nepal. The canopy cover of high-elevation forest was recorded at $>60 \%$ in Garhwal, India [143] and around 65 to $77 \%$ in protected and government forest in the mountains of Nepal [144]. Woody life forms such as buttresses are common features of tropical forest communities [145] but may also be present in sub-tropical and higher elevation forests [146,147]. The presence of different woody life forms has been documented in lower proportions at higher elevations [148,149], which supports our findings on different health and morphological attributes in the study sites. Although there is no satisfactory theory to describe life form development, it might be due to the influence of the humid environment on root tension [145]. However, quantitative studies of forest structure, including life forms, are rarely documented in higher elevation forests [150].

The size of leaves varied according to the species. Since the species in two study sites were completely different, it was difficult to compare leaf size to the precipitation. However, the Rhododendron species in high precipitation region had larger leaves than low precipitation region. The larger leaf sizes in cold and wet climates were also recorded by Peppe et al. [151]. A reduction in leaf size along lower soil phosphorus and rainfall was also recorded by McDonald et al. [152]. In our study, soil properties were uniform in both areas, therefore, the change in leaf size could be associated with precipitation. The study of 
other morphological traits in leaves along different precipitation region is recommended. This study is based on a small number of sample plots as the number of sample plots is determined by topographical and climatic factors as well as time constraints [153]. Roughly 21-108 trees were recorded per plot, which included almost all types and species of trees available in the area. Even though this study is based on few plots, this gives reliable information about structure and composition of mountain forest along contrasting precipitation conditions. In small forest area, the smaller sample size and resulting higher level of sampling error is usually accepted [154]. However, research on large-scale forest monitoring certainly requires the larger sample size for an appropriate precision level [154].

\section{Conclusions}

This study analyzed the variation in the forest structure specially stand variables and forest composition that include species richness, evenness, and diversity in two sites with similar topographic and edaphic factors but different precipitation conditions. The mountain forest in the high precipitation region is dominated by broadleaved forest, whereas in the low precipitation region, coniferous forest is dominant. The mountain forest was characterized by the uneven-aged stand and uneven diameter distribution signifying natural forest condition. The precipitation had a positive impact on forest structure, but had a negative impact on species diversity. However, precipitation had no effect on canopy cover, whereas the leaf area depended on the nature of plant species. Conclusively, precipitation is an important parameter in defining the structure and composition of the forest stand. Although the findings of this study were based on a smaller sample size, they give a clear indication of the importance of this research in understanding species composition and forest structure on two contrasting sides of the mountain range. Although it would be desirable to validate and quantify the findings of this study with more research in this area, it may nevertheless prove very useful in understanding high-elevation forest and in implementing a sustainable management approach.

Author Contributions: Conceptualization, K.P.B. and A.A.; methodology, K.P.B. and A.A.; software, K.P.B., A.K.A. and A.A.; validation, H.B.; formal analysis, K.P.B., A.K.A., A.A. and C.P.; investigation, K.P.B. and S.K.; resources, K.P.B., S.K. and H.B.; data curation, K.P.B., C.P., R.D. and S.K.; writingoriginal draft preparation, K.P.B., A.A. and H.B.; writing-review and editing, A.A. and H.B. All authors have read and agreed to the published version of the manuscript.

Funding: This research received no external funding.

Institutional Review Board Statement: Not applicable.

Informed Consent Statement: Not applicable.

Data Availability Statement: The data presented in this study are available on request from the corresponding author.

Acknowledgments: We would like to thank the Department of National Parks and Wildlife Conservation (DNPWC), Kathmandu and Annapurna Conservation Area Project (ACAP), Pokhara for allowing us to conduct this study. We specially acknowledge CGIAR research program on Forests, Trees and Agroforestry for the partial support to publish this work. We extend our thanks to Department of Tropical Silviculture and Forest Ecology, University of Goettingen, and German Academic Exchange service (PZ 91706208) for the support throughout the study. We express our special gratitude to Ashok Subedi, Rukmangat Subedi, Suman Ghimire, Tulsasi Prasad Dahal, Basu Dev Neupane, Rajesh Gupta, Nabin Bishwokarma, Deepak Pandit, Rijan Tamrakar, Ramesh Prasad Bhatta, Rishi Baral, and Nirmal Magar, as well as the ACAP Bhujung Unit and ACAP Jomsom Unit for their support during our field studies.

Conflicts of Interest: The authors declare no conflict of interest. 


\section{Appendix A}

Table A1. Land cover pattern in the Annapurna range (Source: EU-Copernicus, 2020).

\begin{tabular}{ccc}
\hline Land Cover & Area $\mathbf{( k m}^{\mathbf{2}} \mathbf{)}$ & Percentage \\
\hline Forest & 4300.70 & 36.05 \\
Sparse vegetation & 3095.07 & 25.94 \\
Herbaceous vegetation & 2781.35 & 23.32 \\
Snow /Ice & 1486.45 & 12.46 \\
Cropland & 99.43 & 0.83 \\
Shrubland & 90.45 & 0.76 \\
Built up area & 49.92 & 0.42 \\
Permanent inland water & 18.93 & 0.16 \\
Herbaceous wetland & 7.08 & 0.06 \\
Total & $11,929.37$ & 100.00 \\
\hline
\end{tabular}

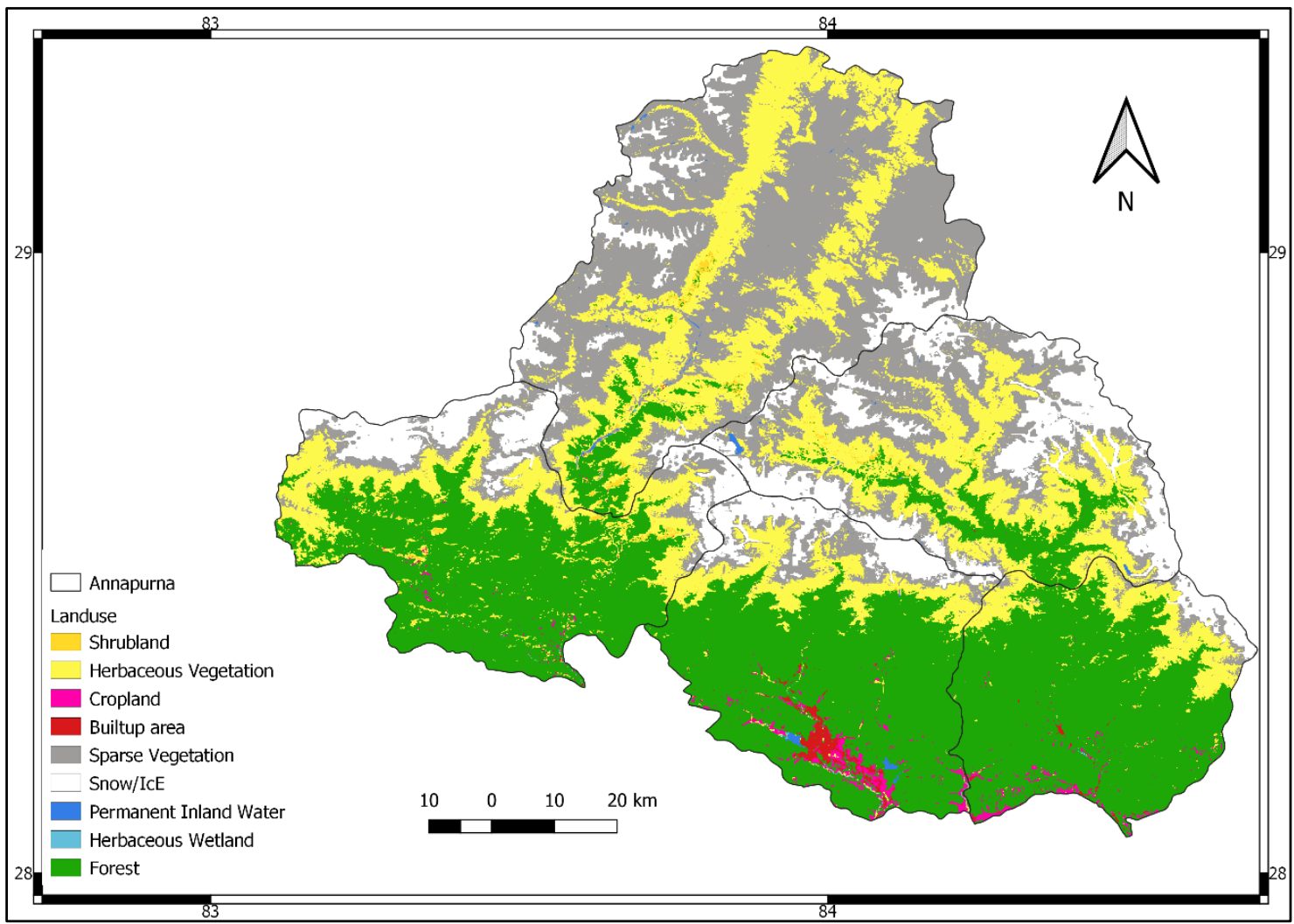

Figure A1. Land cover map of the Annapurna range prepared based on information provided by the European Union Copernicus Land Monitoring Service, 2020.

\section{Appendix B}

Table A2. Method used for testing of soil's physical chemical properties at Soil lab in Nepal.

\begin{tabular}{cc}
\hline Test & Method \\
\hline Soil Texture & Hydrometer method [155] \\
$\mathrm{pH}$ & $1: 2$ soil water suspension [156] \\
Organic matter content $(\mathrm{OM}, \%)$ & Walkely and Black [157] \\
Total Nitrogen content $(\mathrm{N}, \%)$ & Kjeldahl method [158] \\
Available Phosphorus $\left(\mathrm{P}_{2} 0_{5}, \mathrm{~kg} \mathrm{ha}^{-1}\right)$ & Olsen's bicarbonate [159] \\
Available Potassium $\left(\mathrm{K}_{2} 0, \mathrm{~kg} \mathrm{ha}^{-1}\right)$ & Flame photometry [160] \\
\hline
\end{tabular}


Table A3. Rating of soil chemical properties provided by Soil Management Directorate Nepal.

\begin{tabular}{|c|c|}
\hline Properties & Rating \\
\hline $\mathrm{pH}$ & IF > 7.5, "Alkaline", IF > 6.4, "Neutral", "Acidic" \\
\hline O.M. & IF > 5, “High", IF > 2.4, “Medium", "Low" \\
\hline N. & IF $>0.2$, "High", IF > 0.1, "Medium", “Low" \\
\hline $\mathrm{P}_{2} \mathrm{O}_{5}$ & IF > 55, “High", IF > 31, “Medium”, “Low” \\
\hline $\mathrm{K}_{2} \mathrm{O}$ & IF > 280, “High”, IF> 110, “Medium”, “Low” \\
\hline
\end{tabular}

\section{References}

1. Gairola, S.; Rawal, R.S.; Todaria, N.P. Forest vegetation patterns along an altitudinal gradient in sub-alpine zone of west Himalaya, India. Afr. J. Plant Sci. 2008, 2, 042-048.

2. Timilsina, N.; Ross, M.S.; Heinen, J.T. A community analysis of sal (Shorea robusta) forests in the western Terai of Nepal. For. Ecol. Manag. 2007, 241, 223-234. [CrossRef]

3. Ahmad, I.; Ahmad, M.S.A.; Hussain, M.; Ashraf, M.; Ashraf, M.Y. Spatio-temporal variations in soil characteristics and nutrient availability of an open scrub type rangeland in the sub-mountainous Himalayan tract of Pakistan. Pak. J. Bot. 2011, 43, 565-571.

4. Gutiérrez, A.G.; Huth, A. Successional stages of primary temperate rainforests of Chiloé Island, Chile. Pers. Plant. Ecol. Evol. Syst. 2012, 14, 243-256. [CrossRef]

5. Canadell, J.G.; Le Quéré, C.; Raupach, M.R.; Field, C.B.; Buitenhuis, E.T.; Ciais, P.; Conway, T.J.; Gillett, N.P.; Houghton, R.A.; Marland, G. Contributions to accelerating atmospheric $\mathrm{CO}_{2}$ growth from economic activity, carbon intensity, and efficiency of natural sinks. Proc. Natl. Acad. Sci. USA 2007, 104, 18866-18870. [CrossRef]

6. Khaine, I.; Woo, S.Y. An overview of interrelationship between climate change and forests. For. Sci. Technol. 2014, 11, 11-18. [CrossRef]

7. Sullivan, M.J.P.; Talbot, J.; Lewis, S.L.; Phillips, O.L.; Qie, L.; Begne, S.K.; Chave, J.; Cuni-Sanchez, A.; Hubau, W.; Lopez-Gonzalez, G.; et al. Diversity and carbon storage across the tropical forest biome. Sci. Rep. 2017, 7, 39102. [CrossRef]

8. Grubb, P.J. Control of forest growth and distribution on wet tropical mountains: With special reference to mineral nutrition. Annu. Rev. Ecol. Syst. 1977, 8, 83-107. [CrossRef]

9. Lieberman, D.; Lieberman, M.; Peralta, R.; Hartshorn, G.S. Tropical forest structure and composition on a large-scale altitudinal gradient in Costa Rica. J. Ecol. 1996, 84, 137-152. [CrossRef]

10. Koch, G.W.; Sillett, S.C.; Jennings, G.M.; Davis, S.D. The limits to tree height. Nature 2004, 428, 851-854. [CrossRef]

11. Chave, J.; Réjou-Méchain, M.; Búrquez, A.; Chidumayo, E.; Colgan, M.S.; Delitti, W.B.; Duque, A.; Eid, T.; Fearnside, P.M.; Goodman, R.C.; et al. Improved allometric models to estimate the aboveground biomass of tropical trees. Glob. Change Biol. 2014, 20, 3177-3190. [CrossRef] [PubMed]

12. Toledo, M.; Poorter, L.; Peña-Claros, M.; Alarcón, A.; Balcázar, J.; Leaño, C.; Lianque, O.; Vroomans, V.; Zuidema, P.; Bongers, F. Climate is a stronger driver of tree and forest growth rates than soil and disturbance. J. Ecol. 2011, 99, 254-264. [CrossRef]

13. Walther, G.R. Community and ecosystem responses to recent climate change. Phil. Trans. Ro. Soc. B Biol. Sci. 2010, 365, 2019-2024. [CrossRef]

14. Beckage, B.; Osborne, B.; Gavin, D.G.; Pucko, C.; Siccama, T.; Perkins, T. A rapid upward shift of a forest ecotone during 40 years of warming in the Green Mountains of Vermont. Proc. Natl. Acad. Sci. USA 2008, 105, 4197-4202. [CrossRef] [PubMed]

15. Kullman, L.; Öberg, L. Post-Little Ice Age tree line rise and climate warming in the Swedish Scandes: A landscape ecological perspective. J. Ecol. 2009, 97, 415-429. [CrossRef]

16. Field, R.; ÓBrien, E.M.; Whittaker, R.J. Global models for predicting woody plant richness from climate: Development and evaluation. Ecology 2005, 86, 2263-2277. [CrossRef]

17. Francis, A.P.; Currie, D.J. A globally consistent richness-climate relationship for angiosperms. Am. Nat. 2003, 161, 523-536. [CrossRef]

18. Gillman, L.N.; Wright, S.D. Species richness and evolutionary speed: The influence of temperature, water and area. J. Biogeogr. 2014, 41, 39-51. [CrossRef]

19. Goldie, X.; Gillman, L.; Crisp, M.; Wright, S. Evolutionary speed limited by water in arid Australia. Phil. Trans. Ro. Soc. B Biol. Sci. 2010, 277, 2645-2653. [CrossRef] [PubMed]

20. ÓBrien, E. Water-energy dynamics, climate, and prediction of woody plant species richness: An interim general model. J. Biogeogr. 1998, 25, 379-398. [CrossRef]

21. Gentry, A.H. Changes in plant community diversity and floristic composition on environmental and geographical gradients. Ann. Mo. Bot. Gard. 1988, 75, 1-34. [CrossRef]

22. Shrestha, K.B.; Hofgaard, A.; Vandvik, V. Recent tree line dynamics are similar between dry and mesic areas of Nepal, central Himalaya. J. Plant. Ecol. 2015, 8, 347-358. [CrossRef]

23. Ter Steege, H.; Pitman, N.C.; Phillips, O.L.; Chave, J.; Sabatier, D.; Duque, A.; Molino, J.F.; Prévost, M.F.; Spichiger, R.; Castellanos, H.; et al. Continental-scale patterns of canopy tree composition and function across Amazonia. Nature 2006, 443, $444-447$. [CrossRef] [PubMed]

24. Hall, J.B.; Swaine, M. Classification and ecology of closed-canopy forest in Ghana. J. Ecol. 1976, 64, 913-951. [CrossRef] 
25. Bongers, F.; Poorter, L.; Van Rompaey, R.S.A.R.; Parren, M. Distribution of twelve moist forest canopy tree species in Liberia and Cote d'Ivoire: Response curves to a climatic gradient. J. Vegt. Sci. 1999, 10, 371-382. [CrossRef]

26. Engelbrecht, B.M.; Comita, L.S.; Condit, R.; Kursar, T.A.; Tyree, M.T.; Turner, B.L.; Hubbell, S.P. Drought sensitivity shapes species distribution patterns in tropical forests. Nature 2007, 447, 80-82. [CrossRef]

27. Swaine, M.D. Precipitation and soil fertility as factors limiting forest species distributions in Ghana. J. Ecol. 1996, 84, 419-428. [CrossRef]

28. Toledo, M.; Peña-Claros, M.; Bongers, F.; Alarcón, A.; Balcázar, J.; Chuviña, J.; Claudio, L.; Licona, J.C.; Poorter, L. Distribution patterns of tropical woody species in response to climatic and edaphic gradients. J. Ecol. 2012, 100, 253-263. [CrossRef]

29. Mainali, J.; All, J.; Jha, P.K.; Bhuju, D.R. Responses of montane forest to climate variability in the central Himalayas of Nepal. Mt. Res. Dev. 2015, 35, 66-77. [CrossRef]

30. Diekmann, M. Species indicator values as an important tool in applied plant ecology-A review. Basic. Appl. Ecol. 2003, 4, 493-506. [CrossRef]

31. Karpouzoglou, T.; Dewulf, A.; Perez, K.; Gurung, P.; Regmi, S.; Isaeva, A.; Foggin, M.; Bastiaensen, J.; Van Hecken, G.; Zulkafli, Z.; et al. From present to future development pathways in fragile mountain landscapes. Environ. Sci. Pol. 2020, 114, 606-613. [CrossRef]

32. Bhutia, Y.; Gudasalamani, R.; Ganesan, R.; Saha, S. Assessing forest structure and composition along the altitudinal gradient in the state of Sikkim, Eastern Himalayas, India. Forests 2019, 10, 633. [CrossRef]

33. Kalacska, M.; Sanchez-Azofeifa, G.A.; Calvo-Alvarado, J.C.; Quesada, M.; Rivard, B.; Janzen, D.H. Species composition, similarity and diversity in three successional stages of a seasonally dry tropical forest. For. Ecol. Manag. 2004, 200, 227-247. [CrossRef]

34. Feroz, S.M.; Kabir, M.E.; Hagihara, A. Species composition, diversity, and stratification in subtropical evergreen broadleaf forests along a latitudinal thermal gradient in the Ryukyu Archipelago, Japan. Glob. Ecol. Conserv. 2015, 4, 63-72. [CrossRef]

35. Johnson, C.; Chhin, S.; Zhang, J. Effects of climate on competitive dynamics in mixed conifer forests of the Sierra Nevada. For. Ecol. Manag. 2017, 394, 1-12. [CrossRef]

36. Nlungu-Kweta, P.; Leduc, A.; Bergeron, Y. Climate and disturbance regime effects on aspen (Populus tremuloides Michx.) stand structure and composition along an east-west transect in Canada's boreal forest. Forestry Int. J. For. Res. 2017, 90, 70-81.

37. Department of Forest Research and Survey (DFRS). High Mountains and High Himal Forests of Nepal; Forest Resource Assessment (FRA) Nepal, Department of Forest Research and Survey: Kathmandu, Nepal, 2015. Available online: https://frtc.gov.np/ downloadfile/high\%20mountain_1470116949_1579845426.pdf (accessed on 10 October 2020).

38. Carter, H.A. Classification of the Himalaya. Am. Alp. J. 1985, 27, 127-129.

39. European Union, Copernicus Land Monitoring Service (Eu-Copernicus). Copernicus Global Land Service; European Union: Brussels, Belgium, 2020. Available online: https: / / land.copernicus.eu/global/products (accessed on 10 October 2020).

40. Annapurna Conservation Area (ACA). Management plan of Annapurna Conservation Area. Nepal Trust for Nature Conservation, 2009-2012; Nepal Trust for Nature Conservation: Kathmandu, Nepal, 2009.

41. Dhar, O.N.; Nandargi, S. Areas of heavy precipitation in the Nepalese Himalayas. Weather 2005, 60, 354-356. [CrossRef]

42. Biodiversity Profiles Project (BPP). Biodiversity Assessment of Forest Ecosystems of the Western Mid-Hills of Nepal; Biodiversity Profiles Project, Publication No. 7; Department of National Parks and Wildlife Conservation: Kathmandu, Nepal, 1995.

43. Biodiversity Profiles Project (BPP). Biodiversity Assessment of Forest Ecosystems of the Central Mid-Hills of Nepal; Biodiversity Profiles Project, Publication No. 8; Department of National Parks and Wildlife Conservation: Kathmandu, Nepal, 1995.

44. Department of National Parks and Wildlife Conservation (DNPWC). Protected Areas of Nepal; Ministry of Forests and Environment. Department of National Parks and Wildlife Conservation: Kathmandu, Nepal, 2018. Available online: http:/ /www.dnpwc.gov. $\mathrm{np} /$ media/publication/Protected_Area_of_Nepal-2075.pdf (accessed on 12 September 2020).

45. Karger, D.N.; Conrad, O.; Böhner, J.; Kawohl, T.; Kreft, H.; Soria-Auza, R.W.; Zimmermann, N.E.; Linder, H.P.; Kessler, M. Climatologies at high resolution for the Earth's land surface areas. Sci. Dat. 2017, 4, 170122. [CrossRef]

46. Bohner, J. General climatic controls and topo climatic variations in Central and High Asia. Boreas 2006, 35, 279-295. [CrossRef]

47. Government of Nepal, Ministry of Forests and Soil Conservation (GoN/MoFSC). Nepal National Biodiversity Strategy and Action Plan 2014-2020; Government of Nepal, Ministry of Forests and Soil Conservation: Kathmandu, Nepal, 2014. Available online: https:/ / www.cbd.int/doc/world/np/np-nbsap-v2-en.pdf (accessed on 16 September 2020).

48. Karki, R.; Hasson, S.; Schickhoff, U.; Scholten, T.; Böhner, J. Rising Precipitation Extremes across Nepal. Climate 2017, 5, 4. [CrossRef]

49. Karki, R.; Talchabhadel, R.; Aalto, J.; Baidya, S.K. New climatic classification of Nepal. Theor. Appl. Climatol. 2016, 125, 799-808. [CrossRef]

50. Walter, H.; Lieth, H. World Atlas of Climate Diagrams; Part 3; VEB Gustav Fischer Verlag: Jena, Germany, 1967.

51. Guijarro, J.A. Climatol: Climate Tools (Series Homogenization and Derived Products). 2019. Available online: https://cran.rproject.org/web/packages/climatol/index.html (accessed on 16 September 2020).

52. R Studio Team. RStudio: Integrated Development for R; Version 1.3; R Studio: Boston, MA, USA, 2021. Available online: http: //www.rstudio.com/ (accessed on 10 January 2021).

53. Parsons, A.J.; Law, R.D.; Searle, M.P.; Phillips, R.J.; Lloyd, G.E. Geology of the Dhaulagiri-Annapurna-Manaslu Himalaya, Western Region, Nepal. 1: 200,000. J. Map. 2016, 12, 100-110. [CrossRef] 
54. Hodges, K.V.; Parrish, R.R.; Searle, M.P. Tectonic evolution of the central Annapurna range, Nepalese Himalayas. Tectonics 1996, 15, 1264-1291. [CrossRef]

55. Dahal, J.; Chidi, C.L.; Mandal, U.K.; Karki, J.; Khanal, N.R.; Pantha, R.H. Physico-chemical properties of soil in Jita and Taksar area of Lamjung district, Nepal. Geo. J. Nepal. 2018, 11, 45-62. [CrossRef]

56. Pandey, S.; Bhatta, N.P.; Paudel, P.; Pariyar, R.; Maskey, K.H.; Khadka, J.; Thapa, T.B.; Rijal, B.; Panday, D. Improving fertilizer recommendations for Nepalese farmers with the help of soil-testing mobile van. J. Crop. Dev. 2018, 32, 19-32. [CrossRef]

57. Department of Forests (DoF). Community Forest Inventory Guideline; Department of Forests: Kathmandu, Nepal, 2004.

58. Kleinn, C.; Traub, B.; Hoffmann, C. A note on the slope correction and the estimation of the length of line features. Can. J. Forest Res. 2002, 32, 751-756. [CrossRef]

59. Miehe, G. Vegetationsgeographische Untersuchungen im Dhaulagiri-und Annapurna-Himalaya. Diss. Bot. 1982, 66, 1-2.

60. Schickhoff, U. The Upper Timberline in the Himalayas, Hindu Kush and Karakorum: A Review of Geographical and Ecological Aspects. In Mountain Ecosystems; Broll, G., Keplin, B., Eds.; Springer: Berlin/Heidelberg, Germany, 2005; pp. $275-354$.

61. Udas, E. The influence of climate variability on growth performance of Abies spectabilis at tree line of West-Central Nepal. Master's Thesis, University of Greifswald, Greifswald, Germany, 2009.

62. Beckschäfer, P.; Seidel, D.; Kleinn, C.; Xu, J. On the exposure of hemispherical photographs in forests. iForest-Biogeosci. For. 2013, 6, 228-237. [CrossRef]

63. Černý, J.; Pokorný, R.; Haninec, P.; Bednář, P. Leaf area index estimation using three distinct methods in pure deciduous stands. J. Vis. Exp. 2019, 150, e59757. [CrossRef]

64. Getman-Pickering, Z.L.; Campbell, A.; Aflitto, N.; Grele, A.; Davis, J.K.; Ugine, T.A. Leaf Byte: A mobile application that measures leaf area and herbivory quickly and accurately. Meth. Ecol. Evol. 2020, 11, 215-221. [CrossRef]

65. Razali, N.M.; Wah, Y.B. Power comparisons of Shapiro-Wilk, Kolmogorov-Smirnov, Lilliefors and Anderson-Darling tests. J. Stat. Model. Anal. 2011, 2, 21-33.

66. Margalef, R. Information theory in ecology. Gen. Syst. Bul. 1958, 3, 36-71.

67. Pielou, E.C. The measurement of diversity in different types of biological collections. J. Theor. Biol. 1966, 13, 131-144. [CrossRef]

68. Oksanen, J.; Guillaume Blanchet, F.; Friendly, M.; Kindt, R.; Legendre, P.; McGlinn, D.; Minchin, P.R.; ÓHara, R.B.; Simpson, G.L.; Solymos, P.; et al. Vegan: Community Ecology Package. 2019. Available online: https://cran.r-project.org/web/packages/ vegan/index.html (accessed on 10 September 2020).

69. Shannon, C.E.; Wiener, W. The Mathematical Theory of Communication, 1st ed; Urban University Illinois Press: Champaign, IL, USA, $1963 ; 125 p$.

70. Simpson, E.H. Measurement of diversity. Nature 1949, 163, 688. [CrossRef]

71. Gadow, K.V.; Zhang, C.Y.; Wehenkel, C.; Pommerening, A.; Corral-Rivas, J.; Korol, M.; Myklush, S.; Hui, G.Y.; Kiviste, A.; Zhao, X.H. Forest structure and diversity. In Continuous Cover Forestry; Pukkala, T., von Gadow, K., Eds.; Springer: Dordrecht, The Netherlands, 2012; pp. 29-83.

72. Lima, R.B.; Bufalino, L.; Alves Junior, F.T.; Silva, J.A.D.; Ferreira, R.L. Diameter distribution in a Brazilian tropical dry forest domain: Predictions for the stand and species. Anais da Academia Brasileira de Ciências 2017, 89, 1189-1203. [CrossRef]

73. Wickham, H. Tidyverse: Easily Install and Load the ‘Tidyversé. 2019. Available online: https://cran.r-project.org/web/packages / tidyverse/index.html (accessed on 11 September 2020).

74. Wickham, H.; Chang, W.; Henry, L.; Pedersen, T.L. ggplot2: Create Elegant Data Visualizations Using the Grammar of Graphics. 2019. Available online: https://cran.r-project.org/web/packages/ggplot2/index.html (accessed on 20 September 2020).

75. Curtis, J.T.; Mcintosh, R.P. The interrelations of certain analytic and synthetic phytosociological characters. Ecology 1950, 31, 434-455. [CrossRef]

76. Schindelin, J.; Arganda-Carreras, I.; Frise, E.; Kaynig, V.; Longair, M.; Pietzsch, T.; Preibisch, S.; Rueden, C.; Saalfeld, S.; Schmid, B.; et al. Fiji: An open-source platform for biological-image analysis. Nat. Meth. 2012, 9, 676-682. [CrossRef]

77. Beckschäfer, P. Hemispherical_2. 0-Batch Processing Hemispherical and Canopy Photographs with ImageJ-User Manual; University of Göttingen: Göttingen, Germany, 2015. Available online: https://docplayer.net/55833385-Hemispherical_2-0-batch-processinghemispherical-and-canopy-photographs-with-imagej-user-manual-by-philip-beckschafer-january-2015.html (accessed on 12 August 2020).

78. Wilcoxon, F. Individual comparisons by ranking methods. Biom. Bull. 1945, 1, 80-83. [CrossRef]

79. Zobel, D.B.; Singh, S.P. Himalayan forests and ecological generalizations. Bioscience 1997, 47, 735. [CrossRef]

80. Tree Improvement and Silviculture Component (TISC). Forest and Vegetation Types of Nepal; Natural Resource Management Sector Assistance Program Nepal, Tree Improvement and Silviculture Component; Document Series 105; Tree Improvement and Silviculture Component: Kathmandu, Nepal, 2002.

81. Miehe, G.; Pendry, C.; Chaudhary, R.P. Nepal: An Introduction to the Natural History, Ecology and Human Environment of the Himalayas: A Companion Volume to the Flora of Nepal; Royal Botanic Garden Edinburgh: Edinburgh, Scotland, 2015.

82. Rajbhandari, K.R.; Watson, M. Rhododendrons of Nepal (Fascicle of Flora of Nepal); Department of Plant Resources: Kathmandu, Nepal, 2005; Volume 5.

83. Pradhan, S.; Saha, G.K.; Khan, J.A. Ecology of the red panda Ailurus fulgens in the Singhalila National Park, Darjeeling, India. Biol. Conserv. 2001, 98, 11-18. [CrossRef]

84. Tiwari, A.; Jha, P.K. An overview of tree line response to environmental changes in Nepal Himalaya. Trop. Ecol. 2018, 59, 273-285. 
85. Chhetri, P.K. Dendrochronological Analyses and Climate Change Perceptions in Langtang National Park, Central Nepal. In Climate Change and Disaster Impact Reduction; Aryal, K.R., Gadema, Z., Eds.; Northumbria University: Newcastle, UK, 2008.

86. District Development Committee (DDC). Resource Mapping Report of Mustang District; District Development Committee: Jomsom, Mustang, 2014.

87. Christensen, M.; Heilmann-Clausen, J. Forest biodiversity gradients and the human impact in Annapurna Conservation Area, Nepal. Biodvers. Conserv. 2009, 18, 2205-2221. [CrossRef]

88. Jnawali, S.R.; Baral, H.S.; Lee, S.; Acharya, K.P.; Upadhyay, G.P.; Pandey, M.; Shrestha, R.; Joshi, D.; Lamichhane, B.R.; Griffiths, J.; et al. The Status of Nepal's Mammals: The National Red List Series-IUCN; IUCN-SSC and National Trust of Nature Conservation: Kathmandu, Nepal, 2011.

89. Bista, D.; Shrestha, S.; Sherpa, P.; Thapa, G.J.; Kokh, M.; Lama, S.T.; Khanal, K.P.; Thapa, A.; Jnawali, S.R. Distribution and habitat use of red panda in the Chitwan-Annapurna Landscape of Nepal. PLoS ONE 2017, 12, e0178797. [CrossRef] [PubMed]

90. Bhattarai, S.; Chaudhary, R.P.; Taylor, R.S. The use of plants for fencing and fuelwood in Mustang District, Trans-Himalayas, Nepal. Sci. World 2009, 7, 59-63. [CrossRef]

91. Chapagain, N.R.; Chetri, M. Biodiversity Profile of Upper Mustang; National Trust for Nature Conservation, Annapurna Conservation Area Project, Upper Mustang Biodiversity Conservation Project: Kathmandu, Nepal, 2006.

92. Dobremez, J.F. Nepal: Ecology and Biogeography; Éditions du Centre National de la Recherche Scientifique: Paris, France, 1976.

93. Stainton, J.D.A. Forest of Nepal; John Murrey: London, UK, 1972.

94. Bhuju, S.; Gauchan, D.P. Taxus wallichiana (Zucc.), an Endangered Anti-Cancerous Plant: A Review. Int. J. Res. 2018, 5, 10-21.

95. Leilei, L.; Jianrong, F.; Yang, C. The relationship analysis of vegetation cover, precipitation and land surface temperature based on remote sensing in Tibet, China. In Proceedings of the IOP Conference Series: Earth and Environmental Science (Vol. 17, No. 1, p. 012034), International Symposium on Remote Sensing of Environment (ISRSE35), Beijing, China, $22-26$ April 2013.

96. Joshi, N.; Gyawali, P.; Sapkota, S.; Neupane, D.; Shrestha, S.; Shrestha, N.; Tuladhar, F.M. Analyzing the effect of climate change (precipitation and temperature) on vegetation cover of Nepal using time-series MODIS images. Ann. Photogram. Remote Sens. Spatial Inf. Sci. 2019, 209-216.

97. Daniels, L.D.; Veblen, T.T. Spatiotemporal influences of climate on altitudinal tree line in northern Patagonia. Ecology 2004, 85, 1284-1296. [CrossRef]

98. Elliott, G.P.; Kipfmueller, K.F. Multi-scale influences of climate on upper tree line dynamics in the southern Rocky Mountains, USA: Evidence of intraregional variability and bioclimatic thresholds in response to twentieth century warming. Ann. Assoc. Am. Geogr. 2011, 101, 1181-1203. [CrossRef]

99. Danby, R.K.; Hik, D.S. Variability, contingency, and rapid change in recent subarctic alpine tree line dynamics. J. Ecol. 2007, 95, 352-363. [CrossRef]

100. Elliott, G.P.; Kipfmueller, K.F. Multi-scale influences of slope aspect and spatial pattern on ecotonal dynamics at upper tree line in the southern Rocky Mountains, USA. Arct. Antarct. Alp. Res. 2010, 42, 45-56. [CrossRef]

101. Paudel, P.K.; Bhattarai, B.P.; Kindlmann, P. An overview of the biodiversity in Nepal. In Himalayan Biodiversity in the Changing World; Kindalmann, P., Ed.; Springer: Dordrecht, The Netherlands, 2012; pp. 1-40.

102. Bhuju, D.R.; Gaire, N.P. Tree-Rings and Tree Lines of Nepal Himalaya; Research Synopsis, Commemorating Symposium Himalayan Tree-Line; Tree-Ring Society of Nepal: Katmandu, Nepal, 2017.

103. Singh, J.S.; Singh, S.P. Forest vegetation of the Himalaya. The Bot. Rev. 1987, 53, 80-192. [CrossRef]

104. Vetaas, O.R.; Grytnes, J.A. Distribution of vascular plant species richness and endemic richness along the Himalayan elevation gradient in Nepal. Glob. Ecol. Biogeogr. 2002, 11, 291-301. [CrossRef]

105. Paudel, S.; Vetaas, O.R. Effects of topography and land use on woody plant species composition and beta diversity in an arid Trans-Himalayan landscape, Nepal. J. Mt. Sci. 2014, 11, 1112-1122. [CrossRef]

106. Kharal, D.K.; Meilby, H.; Rayamajhi, S.; Bhuju, D.; Thapa, U.K. Tree ring variability and climate response of Abies spectabilis along an elevation gradient in Mustang, Nepal. Banko Janakari 2014, 24, 3-13. [CrossRef]

107. Kharkwal, G.; Mehrotra, P.; Rawat, Y.S.; Pangtey, Y.P.S. Phytodiversity and growth form in relation to altitudinal gradient in the Central Himalayan (Kumaun) region of India. Curr. Sci. 2005, 873-878.

108. Manish, K.; Telwala, Y.; Nautiyal, D.C.; Pandit, M.K. Modelling the impacts of future climate change on plant communities in the Himalaya: A case study from Eastern Himalaya, India. Model. Earth Syst. Environ. 2016, 2, 92. [CrossRef]

109. Sharma, N.; Behera, M.D.; Das, A.P.; Panda, R.M. Plant richness pattern in an elevation gradient in the Eastern Himalaya Biodivers. Conserv. 2019, 28, 2085-2104. [CrossRef]

110. Ghimire, B.; Mainali, K.P.; Lekhak, H.D.; Chaudhary, R.P.; Ghimeray, A.K. Regeneration of Pinus wallichiana AB Jackson in a trans-Himalayan dry valley of north-central Nepal. Himal. J. Sci. 2010, 6, 19-26.

111. Måren, I.E.; Karki, S.; Prajapati, C.; Yadav, R.K.; Shrestha, B.B. Facing north or south: Does slope aspect impact forest stand characteristics and soil properties in a semiarid trans-Himalayan valley? J. Arid. Environ. 2015, 121, 112-123. [CrossRef]

112. Olivero, A.M.; Hix, D.M. Influence of aspect and stand age on ground flora of Southeastern Ohio forest ecosystems. Plant Ecol. 1998, 139, 177-187. [CrossRef]

113. Schickhoff, U. Contributions to the synecology and syntaxonomy of West Himalayan coniferous forest communities. Phytoeco. 1996, 26, 537-581. [CrossRef] 
114. Zavaleta, E.S.; Shaw, M.R.; Chiariello, N.R.; Thomas, B.D.; Cleland, E.E.; Field, C.B.; Mooney, H.A. Grassland responses to three years of elevated temperature, CO2, precipitation, and N deposition. Ecol. Monogr. 2003, 73, 585-604. [CrossRef]

115. Stevens, M.H.H.; Shirk, R.; Steiner, C.E. Water and fertilizer have opposite effects on plant species richness in a mesic early successional habitat. Plant. Ecol. 2006, 183, 27-34. [CrossRef]

116. Yang, H.; Li, Y.; Wu, M.; Zhang, Z.H.E.; Li, L.; Wan, S. Plant community responses to nitrogen addition and increased precipitation: The importance of water availability and species traits. Glob. Change. Biol. 2011, 17, 2936-2944. [CrossRef]

117. Yoda, K. A preliminary survey of forest vegetation of eastern Nepal. J. Coll. Art. Sci. 1967, 5, 99-140.

118. Stevens, G.C. The elevational gradient in altitudinal range: An extension of Rapoport's latitudinal rule to altitude. Am. Nat. 1992, 140, 893-911. [CrossRef]

119. Bhattarai, K.R.; Vetaas, O.R. Can Rapoport's rule explain tree species richness along the Himalayan elevation gradient, Nepal? Divers. Distb. 2006, 12, 373-378. [CrossRef]

120. Kluge, J.; Worm, S.; Lange, S.; Long, D.; Böhner, J.; Yangzom, R.; Miehe, G. Elevational seed plants richness patterns in Bhutan, Eastern Himalaya. J. Biogeogr. 2017, 44, 1711-1722. [CrossRef]

121. Stan, K.; Sanchez-Azofeifa, A. Tropical dry forest diversity, climatic response, and resilience in a changing climate. Forests 2019, 10, 443. [CrossRef]

122. Kushwaha, S.P.S.; Nandy, S. Species diversity and community structure in sal (Shorea robusta) forests of two different precipitation regimes in West Bengal, India. Biodivers. Conserv. 2012, 21, 1215-1228. [CrossRef]

123. Khaine, I.; Woo, S.Y.; Kang, H.; Kwak, M.; Je, S.M.; You, H.; Lee, T.; Jang, J.; Lee, H.K.; Lee, E.; et al. Species diversity, stand structure, and species distribution across a precipitation gradient in tropical forests in Myanmar. Forests 2017, 8, 282. [CrossRef]

124. Osland, M.J.; Feher, L.C.; Griffith, K.T.; Cavanaugh, K.C.; Enwright, N.M.; Day, R.H.; Stagg, C.L.; Krauss, K.W.; Howard, R.J.; Grace, J.B.; et al. Climatic controls on the global distribution, abundance, and species richness of mangrove forests. Ecol. Monogr. 2017, 87, 341-359. [CrossRef]

125. Staver, A.C.; Archibald, S.; Levin, S. Tree cover in sub-Saharan Africa: Rainfall and fire constrain forest and savanna as alternative stable states. Ecology 2011, 92, 1063-1072. [CrossRef]

126. Sharma, C.M.; Ghildiyal, S.K.; Gairola, S.; Suyal, S. Vegetation structure, composition, and diversity in relation to the soil characteristics of temperate mixed broad-leaved forest along an altitudinal gradient in Garhwal Himalaya. Indian J. Sci. Technol. 2009, 2, 39-45. [CrossRef]

127. Pandey, K.P.; Adhikari, Y.P.; Weber, M. Structure, composition and diversity of forest along the altitudinal gradient in the Himalayas, Nepal. Appl. Ecol. Environ. Res. 2016, 14, 235-251. [CrossRef]

128. Bhat, J.A.; Kumar, M.; Negi, A.K.; Todaria, N.P.; Malik, Z.A.; Pala, N.A.; Kumar, A.; Shukla, G. Altitudinal gradient of species diversity and community of woody vegetation in the Western Himalayas. Glob. Eco. Cons. 2020, $24, \mathrm{e} 01302$.

129. Maçaneiro, J.P.D.; Oliveira, L.Z.; Seubert, R.C.; Eisenlohr, P.V.; Schorn, L.A. More than environmental control at local scales: Do spatial processes play an important role in floristic variation in subtropical forests? Acta Bot. Bras. 2016, 30, 183-192. [CrossRef]

130. Sevegnani, L.; Uhlmann, A.; de Gasper, A.L.; Meyer, L.; Vibrans, A.C. Climate affects the structure of mixed rain forest in southern sector of Atlantic domain in Brazil. Acta Oecol. 2016, 77, 109-117. [CrossRef]

131. Muñoz Mazón, M.; Klanderud, K.; Finegan, B.; Veintimilla, D.; Bermeo, D.; Murrieta, E.; Delgado, D.; Sheil, D. How forest structure varies with elevation in old growth and secondary forest in Costa Rica. For. Ecol. Manag. 2020, 469, 118191. [CrossRef]

132. Komárková, V.; Webber, P.J. An Alpine Vegetation Map of Niwot Ridge, Colorado. Arct. Alp. Res. 1978, 10, 1-29. [CrossRef]

133. Chaurasia, O.P.; Brahma, S. Cold Desert Plants; Volume III-Changthang Valley; Field Research Laboratory, DRDO: Leh, Jammu; Kashmir, India, 1997; Volume 3, p. 85.

134. Terra, M.D.C.N.S.; Santos, R.M.D.; Prado Júnior, J.A.D.; de Mello, J.M.; Scolforo, J.R.S.; Fontes, M.A.L.; Schiavini, I.; dos Reis, A.A.; Bueno, I.T.; Magnago, L.F.S.; et al. Water availability drives gradients of tree diversity, structure, and functional traits in the Atlantic-Cerrado-Caatinga transition, Brazil. J. Plant. Ecol. 2018, 11, 803-814. [CrossRef]

135. Sinha, S.; Badola, H.K.; Chhetri, B.; Gaira, K.S.; Lepcha, J.; Dhyani, P.P. Effect of altitude and climate in shaping the forest compositions of Singalila National Park in Khangchendzonga Landscape, Eastern Himalaya, India. J. Asia-Pac. Biodivers. 2018, 11, 267-275. [CrossRef]

136. Hiltner, U.; Bräuning, A.; Gebrekirstos, A.; Huth, A.; Fischer, R. Impacts of precipitation variability on the dynamics of a dry tropical montane forest. Ecol. Model. 2016, 320, 92-101. [CrossRef]

137. Beard, J.S. Historical and ecological development of evergreen broadleaved forest of Australia. Vegt. Sci. For. 1995, 12a, 179-187.

138. Duchesne, L.; Ouimet, R. Relationships between structure, composition, and dynamics of the pristine northern boreal forest and air temperature, precipitation, and soil texture in Quebec (Canada). Intl. J. For. Res. 2009, 2009, 398389. [CrossRef]

139. Shrestha, B.B.; Ghimire, B.; Lekhak, H.D.; Jha, P.K. Regeneration of tree line birch (Betula utilis D. Don) forest in a trans-Himalayan dry valley in central Nepal. Mt. Res. Dev. 2007, 27, 259-267. [CrossRef]

140. Dar, J.A.; Sundarapandian, S. Patterns of plant diversity in seven temperate forest types of Western Himalaya, India. J. Asia-Pac. Biodivers. 2016, 9, 280-292. [CrossRef]

141. Schwab, N. Sensitivity and Response of Alpine Tree Lines to Climate Change-Insights from a Krummholz Tree Line in Rolwaling Himal, Nepal. 2019. Available online: https:/ / ediss.sub.uni-hamburg.de/handle/ediss / 8041 (accessed on 24 October 2020).

142. Vetaas, O.R. The effect of environmental factors on the regeneration of Quercus semicarpifolia Sm. in central Himalaya, Nepal. Plant. Ecol. 2000, 146, 137-144. [CrossRef] 
143. Uniyal, P.; Pokhriyal, P.; Dasgupta, S.; Bhatt, D.; Todaria, N.P. Plant diversity in two forest types along the disturbance gradient in Dewalgarh Watershed, Garhwal Himalaya. Curr. Sci. 2010, 98, 938-943.

144. Måren, I.E.; Sharma, L.N. Managing biodiversity: Impacts of legal protection in mountain forests of the Himalayas. Forests 2018, 9, 476. [CrossRef]

145. Richards, P.W.; Frankham, R.; Walsh, R.P.D. The Tropical Rain Forest: An Ecological Study; Cambridge University Press: Cambridge, UK, 1996.

146. Francis, W.D. The Development of Buttresses in Queensland Trees; Government Printer: Pretoria, South Africa, 1924.

147. Nicoll, B.C.; Ray, D. Adaptive growth of tree root systems in response to wind action and site conditions. Tree Physiol. 1996, 16, 891-898. [CrossRef] [PubMed]

148. Hernández, L.; Dezzeo, N.; Sanoja, E.; Salazar, L.; Castellanos, H. Changes in structure and composition of evergreen forests on an altitudinal gradient in the Venezuelan Guayana Shield. Revista de Biología Tropical 2012, 60, 11-33. [CrossRef] [PubMed]

149. Baur, G.N. The Ecological Basis of Rainforest Management; Library AN: 113414, 1965; Food and Agricultural Organization: Rome, Italy, 1965. Available online: http:/ / www.fao.org/3/ax363e/ax363e.pdf (accessed on 1 September 2020).

150. Berry, P.E.; Holst, B.K.; Yatskievych, K.; Manara, B. Flora of Venezuelan Guayana. Springer 1998, 53, $1017-1018$.

151. Peppe, D.J.; Royer, D.L.; Cariglino, B.; Oliver, S.Y.; Newman, S.; Leight, E.; Wright, I.J.; Enikolopov, G.; Fernandez-Burgos, M.; Herrera, F.; et al. Sensitivity of leaf size and shape to climate: Global patterns and paleoclimatic applications. New. Phyt. 2011, 190, 724-739. [CrossRef]

152. McDonald, P.G.; Fonseca, C.R.; Overton, J.M.; Westoby, M. Leaf-size divergence along rainfall and soil-nutrient gradients: Is the method of size reduction common among clades? Funct. Ecol. 2003, 17, 50-57. [CrossRef]

153. Forest and Agriculture Organization (FAO). Sustainable Forest Management (SFM) Toolbox, Forest Inventory; Forest and Agriculture Organization of United Nations, Rome, Italy. 2021. Available online: http://www.fao.org/sustainable-forest-management/toolbox/ modules / forest-inventory/basic-knowledge/en/?type=111 (accessed on 18 June 2021).

154. Fischer, C.; Kleinn, C.; Fehrmann, L.; Fuchs, H.; Panferov, O. A national level forest resource assessment for Burkina Faso-A field based forest inventory in a semiarid environment combining small sample size with large observation plots. For. Ecol. Manag. 2011, 262, 1532-1540. [CrossRef]

155. Bouyoucos, G.J. Directions for making mechanical analyses of soils by the hydrometer method. Soil. Sci. 1936, 42, 225-230. [CrossRef]

156. Jackson, M.L. Soil chemical analysis, pentice hall of India Pvt. Ltd., New Delhi, India 1973, 498, 151-154.

157. Walkley, A.; Black, I.A. An examination of the Degtjareff method for determining soil organic matter, and a proposed modification of the chromic acid titration method. Soil. Sci. 1934, 37, 29-38. [CrossRef]

158. Bremner, J.M.; Mulvaney, C.S. Nitrogen total. In Method of Soil Analysis; Agron. No. 9, Part 2: Chemical and Microbiological Properties, 2nd ed.; Page, A.L., Ed.; American Society of Agronomy: Madison, WI, USA, 1982.

159. Olsen, S.R. Estimation of Available Phosphorus in Soils by Extraction with Sodium Bicarbonate; US Department of Agriculture: Washington, DC, USA, 1954.

160. Toth, S.J.; Prince, A.L. Estimation of cation-exchange capacity and exchangeable Ca, K, and Na contents of soils by flame photometer techniques. Soil. Sci. 1949, 67, 439-446. [CrossRef] 